\title{
Genetic genealogy for the study of Puerto Rican, Spanish, and Portuguese family history: lessons from the Sotomayor, Colón, and Pereira families
}

Received: 12 September 2018 Accepted: 25 November 2018

KEYWORDS: genetic genealogy; Puerto Rico; Iberia; Sotomayor; Colón; Pereira; Y-DNA

\section{Antonio Sotomayor}

Abstract: Genetic genealogy is a rapidly growing field. The potential for genetics to make genealogical connections and break brick walls is starting to be untapped. This is more so for Latin American and Caribbean societies where limited or non-existent documentation is a reality. This article uses advanced genetic testing to draw genealogies for a particular set of Puerto Rican families, the Sotomayor and Colón families, with connections to the Iberian Pereira lineage. In the critical analysis of the existing fragmented and isolated documentation with advanced genetic testing, mainly Y-DNA, and in its proper historical context, long-standing brick walls have been broken. The study also illustrates, through the prism of genetics, the complex anthroponymy system of Iberian surnames in the American context, which gave a legitimate and significant role to maternal ancestry. As one of the very few instances of a Y-DNA genetic match between two men of different surnames at the edge of genealogical time frames, this study offers insights into the larger use of genetics for genealogy and anthroponymy.

\section{Introduction}

The Sotomayor family from Puerto Rico has not been properly understood among local genealogists. ${ }^{1}$ (Not a single article about this family has appeared in the Puerto Rican Genealogical Society's journal since its tenth volume in 1988.) This is due to the lack of documentation from the sixteenth, seventeenth, and eighteenth centuries, which presents a great challenge to genealogists. ${ }^{2}$ Looking for alternatives to brick walls in Puerto Rican genealogy, this study incorporates the field of genetics and employs a genetic-genealogy methodology to break those brick walls. New genetic, genealogical, and historical data link two families in Puerto Rico, the Sotomayor and the Colón families, with Iberian roots in the Pereira lineage from Portugal. Altogether, they help to break long-standing brick walls in these families' genealogies, while offering clues into deeper medieval Iberian history, a unique case among Ibero-American genealogy, genetics, and family history. (This is in reference to Y-DNA and genealogy, not in relation to admixtures and biological or anthropological terms. ${ }^{3}$ ) It is not the intent of this article to enter into the legitimation of racial privilege in the construction of Latin American nationhoods (for which see the 2015 special issue of Social Studies of Science ${ }^{4}$ ). An important detail to consider is that one participant in this study is Afro-Puerto Rican, illustrating the point that $Y$ chromosomes and phenotypes are not in correlation. The main motivation to write this article was to contribute to the field of family history, circumscribed mainly to the reconstruction of the genealogy of two Puerto Rican families combining history and genetics.

Popular lore and long-standing legend say that the Sotomayor family from Puerto Rico's north-west descend from Galician noble Don Cristóbal de Sotomayor, who settled in the island in 1509 and died during the indigenous rebellion in 1511 shortly after establishing the Villa de Sotomayor. ${ }^{5}$ The present study refutes this legend, at least with regard to the direct male descendants of Juan de Sotomayor, who was born in Aguada c.1740. In doing so, a new genealogy is offered, supported by - and actually only possible with - genetic data, particularly Y-DNA. Similarly, there has been research done on several branches of the Colón family, some of which can be traced to the sixteenth century, allegedly related to the family of Admiral Don Cristóbal Colón (Christopher Columbus). ${ }^{6}$ But the branch participating in the present study had not been able to go beyond the early nineteenth century. Of particular interest is the fact that the genetic matching of these two families places their ancestor in common some 500 years ago, beyond the genealogical time frame, which for Iberian-American societies could be between 300 and 500 years before the present. The genealogical journey between these families also allows us to observe the intricate and complex anthroponymy system of Iberian-American surnames that incorporates maternal surnames in legitimate offspring.

๑ 2019 The Author(s). This is an open access article distributed under the terms of the Creative Commons Attribution License (http://creativecommons.org/ licenses/by/4.0/) 
In the pages that follow, I will briefly discuss the Sotomayor lineage in Spain, before discussing the Sotomayors in Puerto Rico at the start of the European colonization in the 1500s. I will then present the methodology and genetic results, followed by a genealogical-genetic interpretation. I conclude that not only has genetic genealogy helped in clarifying the genealogy of some branches of the Sotomayor and Colón families in Puerto Rico, but that these results provide interesting information to understand the background of one of the most important lineages of the Iberian Peninsula: the Galician/Asturian Froilaz/Traba family.

\section{The Sotomayor lineage}

The Sotomayor lineage is approximately 850 years old and has a recognized origin. Historian Suso Vila acknowledges the traditional genealogies that identify Men Páez Sorredea (a.k.a. Sorred, Sorredea, Sorrez) as the founder of the lineage in the middle of the twelfth century. Men Páez stood out at the Conquest of Almería in 1147 and, because of his services, King Alfonso VII rewarded him with the lordship over the Valley of Souto (Pontevedra) (see Figure 1), which he named Souto Maior. ${ }^{7}$ Nonetheless, Vila also proposes an alternative to the lineage's origins. He argues that the lordship over the valley of Souto was granted by King Alfonso VII to a knight by the name of Pelagio Subredina in 1141 to hold the Castellum Sancti Pelagii de Luto, today Pontesampaio, and by doing so protect the southern route of the Camino de Santiago against Portuguese and/or Muslim advances. ${ }^{8,9}$ This Pelagio Subredina, or perhaps a descendant of the same name,

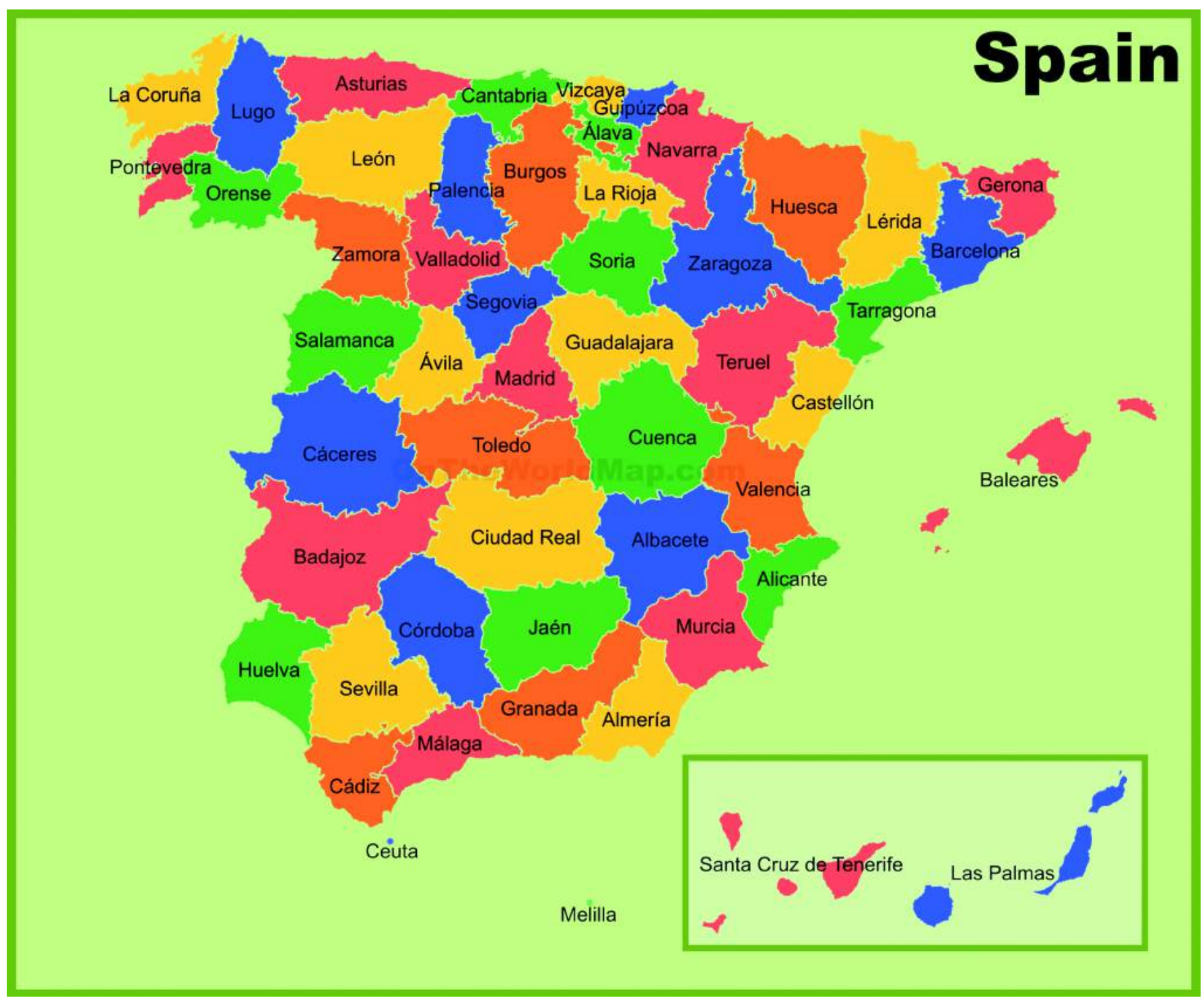

Figure 1. Map of Spanish provinces. Galicia is the north-west provinces of La Coruña, Lugo, Pontevedra, and Orense. Image taken with permission from On the World Map, http://ontheworldmap.com/spain/spain-provinces-map.html. 
appears again in 1197/98 as a member of King Fernando II's royal court and holding several castles in the lands of Toroño and Limia in the vicinity of the Valley of Souto. ${ }^{10}$ Vila thinks this Pelagio Subredina could have been Paio Sorredea, Men Páez's father. In any case, the Sotomayor family already had a seigniorial castle in Pontevedra, and had achieved ricohombre status. ${ }^{11,12}$ (Ricohombres was a term used to categorize the high nobility in medieval lberia, sometimes used synonymously with counts and barons.) The Sotomayors had adopted a coat of arms (Figure 2) as an iconographic representation of the lineage by the twelfth century. From then on, the Sotomayor family became preeminent members of Galician and Castilian nobility, developing a strong "sense of lineage."13 The Sotomayors throughout Iberia (Galicia, Extremadura, Andalusia, Castile, Canary Islands, Portugal) descend from the Galician root. ${ }^{14,15}$

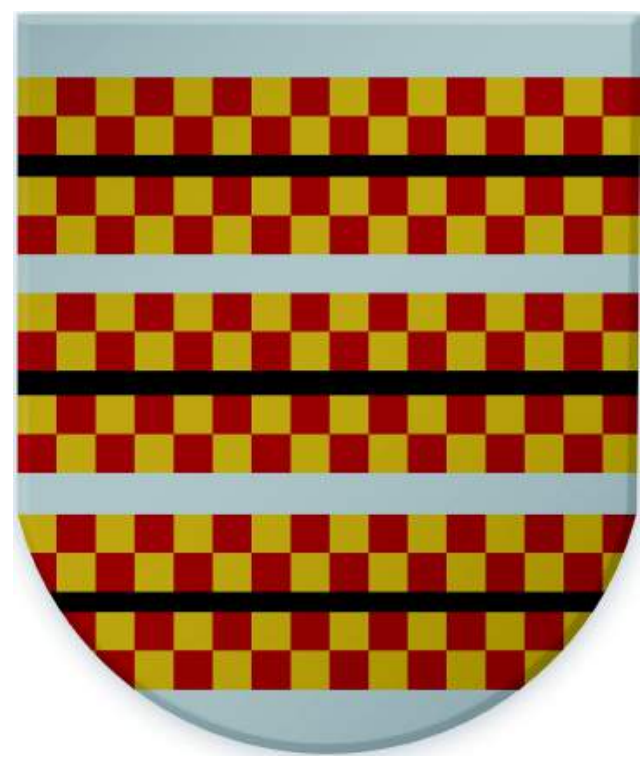

Figure 2. Coat of arms of the Sotomayor lineage, rendition by and courtesy of Yamil Fuentes.

\section{The Sotomayors in Puerto Rico}

People with the surnames Sotomayor and Colón have been in Puerto Rico since the conquest and early colonization in the 1500s. Cristóbal Colón (Christopher Columbus) arrived on the island in 1493. His descendants lived on the island by the end of the sixteenth century and, as a result of marriages with other noble families, produced lineages with compound surnames such as Colón de Luyando, Colón de Torres, Ramos Colón, Colón de Bonilla, and Colón de Santiago. Settling early in the town of Coamo, ${ }^{16}$ the Colóns spread through towns such as San Germán, Arecibo, and Aguada during the seventeenth century, holding military ranks such as captains, sergeants, alférez [junior officers], corporals, and lieutenants. Like the Sotomayors, the Colóns were wealthy landowners and slave-owners and held the honorific titles of Don and Doña. There are various historical and genealogical works on these families, for example by members of the Puerto Rican Genealogical Society David Cuesta Camacho, David Stark, and Edmund Colón Gaulden ${ }^{17}$ so I will focus on the Sotomayor (as well as the Colón de Santiago) families, which have not been studied as much.

The Sotomayors are now widely spread throughout the towns of Aguada, Moca, Isabela, Aguadilla, San Sebastián, Lares, Quebradillas, Camuy, and Añasco, among many more in Puerto Rico's north-west (see Figure 3). Many of these branches merge in Aguada in the late seventeenth

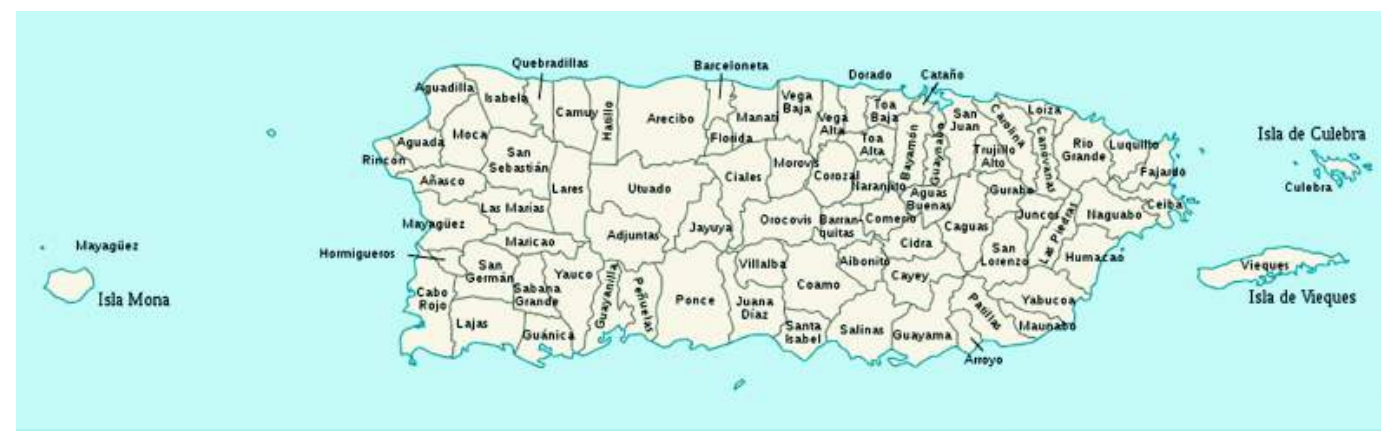

Figure 3. Present-day towns in Puerto Rico. From Wikimedia Commons (with licence). 
and early eighteenth centuries, but the documentation is very limited and fragmented. Many belonged to the urban militias, owned land and slaves, and married into other noble families in the region. Some of their slaves adopted the surname Soto or Sotomayor and, as such, might not have the same biological connection. Others married into different families to produce racially and ethnically rich families.

I can document my Sotomayor genealogy to my 5th-great-grandfather Don Juan de Sotomayor, and to his possible father, Don Juan de Soto Hernández, who lived in the eighteenth century (Figure 4). (I must mention also that there was a "Soto Hernández de Andújar" family from Vigo, Galicia, which migrated to Santo Domingo (later Dominican Republic) in the mid 1600 s. ${ }^{18}$ However, this family appears to be settled in Santo Domingo, and only travelled to Puerto Rico late in the eighteenth century.) Figure 5 shows the death record of Catalino Sotomayor $y$ Tirado (my 3rd-grand-uncle), as reported by my great-great-grandfather Alberto Sotomayor y Tirado, and Figure 6 is the birth record of my grandfather, Antonio Sotomayor Mendez. ${ }^{19}$

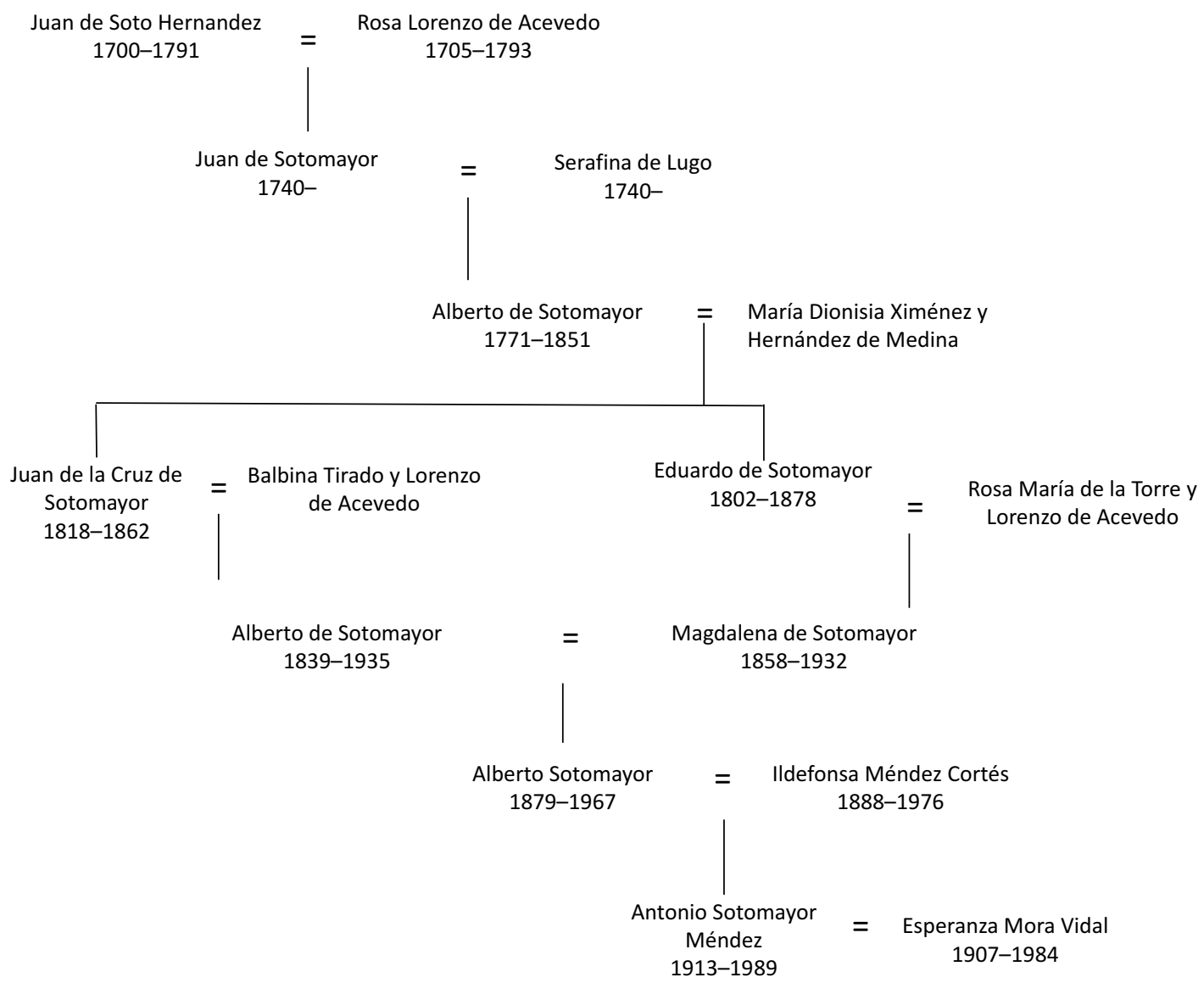

Figure 4. Sotomayor ancestors of my grandfather Sotomayor.

The relationship with Don Juan de Soto Hernández is based on the annotations made by the lawyer and renowned genealogist Rafael Reichard Sapia in the early twentieth century. In his notebooks there is an annotation of the death record of Don Juan de Soto Hernández from August 6,1791 , in Moca. ${ }^{20}$ Moca's parish books of death no longer exist, which makes the Reichard Sapia transcription the only remaining source. ${ }^{21}$ The record used to say that he was from Aguada and that he died at the age of one-hundred-and-twelve. I think the age of death was an error and he most probably died, like many other Sotomayors, at around ninety years old, thus born c.1700.

There is the notion that the Sotomayor family is an old one in the region. The U.S. Supreme Court Justice Hon. Sonia Sotomayor, whose ancestors go back to the town of San Sebastián in the eighteenth century, states in her autobiography, My Beloved World, that "Still older stories survive in hand-me-down recollections beyond any living soul's direct experience: The Sotomayors, I heard, might be descendants of Puerto Rican Pioneers." ${ }^{22}$ A document from the early 1800s provides a similar authoritative perspective, although not official. In 1820 Aguada, a young man named Don Lorenzo de Sotomayor declared his wish to marry Doña Juana Urbano Cabán. The priest and lady's uncle, Don Manuel Cabán, protested, saying that the boy did not deserve his delicate and noble niece. But the petition persisted and on October 25,1821 


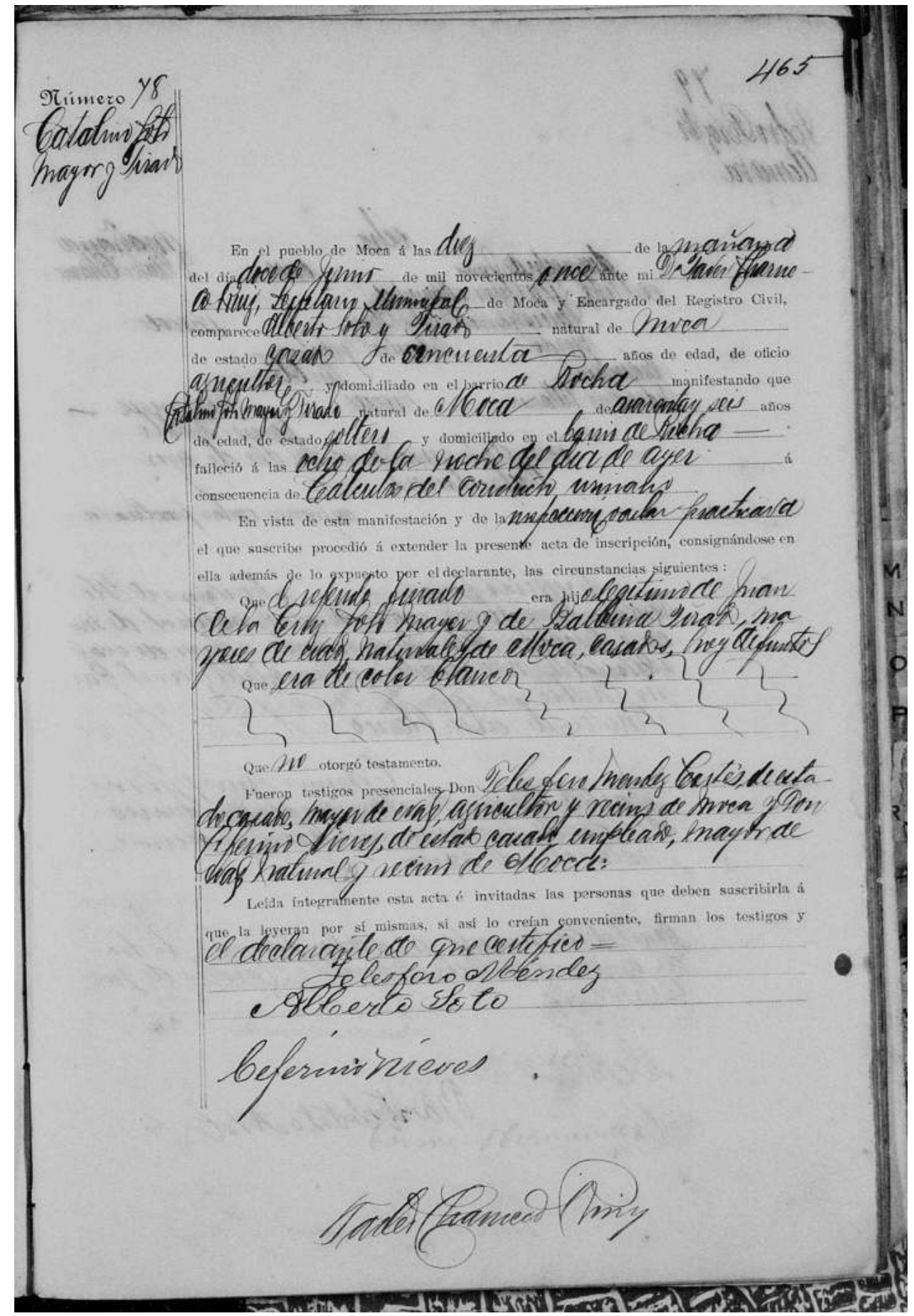

Figure 5. Death record of Catalino Sotomayor y Tirado (my 3rd-grand-uncle) from 1911, son of Juan de la Cruz de Sotomayor and Balbina Tirado. The person reporting the event was his brother and my great-great-grandfather Alberto Sotomayor y Tirado.

the priest declared that she was from her father's side of "European Spaniards" and that Lorenzo was "of the first families of the village, white on every ancestral branch, without racial mixing." ${ }^{23}$ The priest later declared that Don Lorenzo was of "clarified ancestry" (ascendencia esclarecida) and that he descended from a prominent family, which indicates that his genealogy was known. This case is important. Puerto Rico's population during the seventeenth century was not large. When Aguada was founded between 1648 and $1692,{ }^{24}$ there were only three other villages on the island (San Germán, Coamo and Arecibo) outside of the capital San Juan. By the end of the seventeenth century, San 


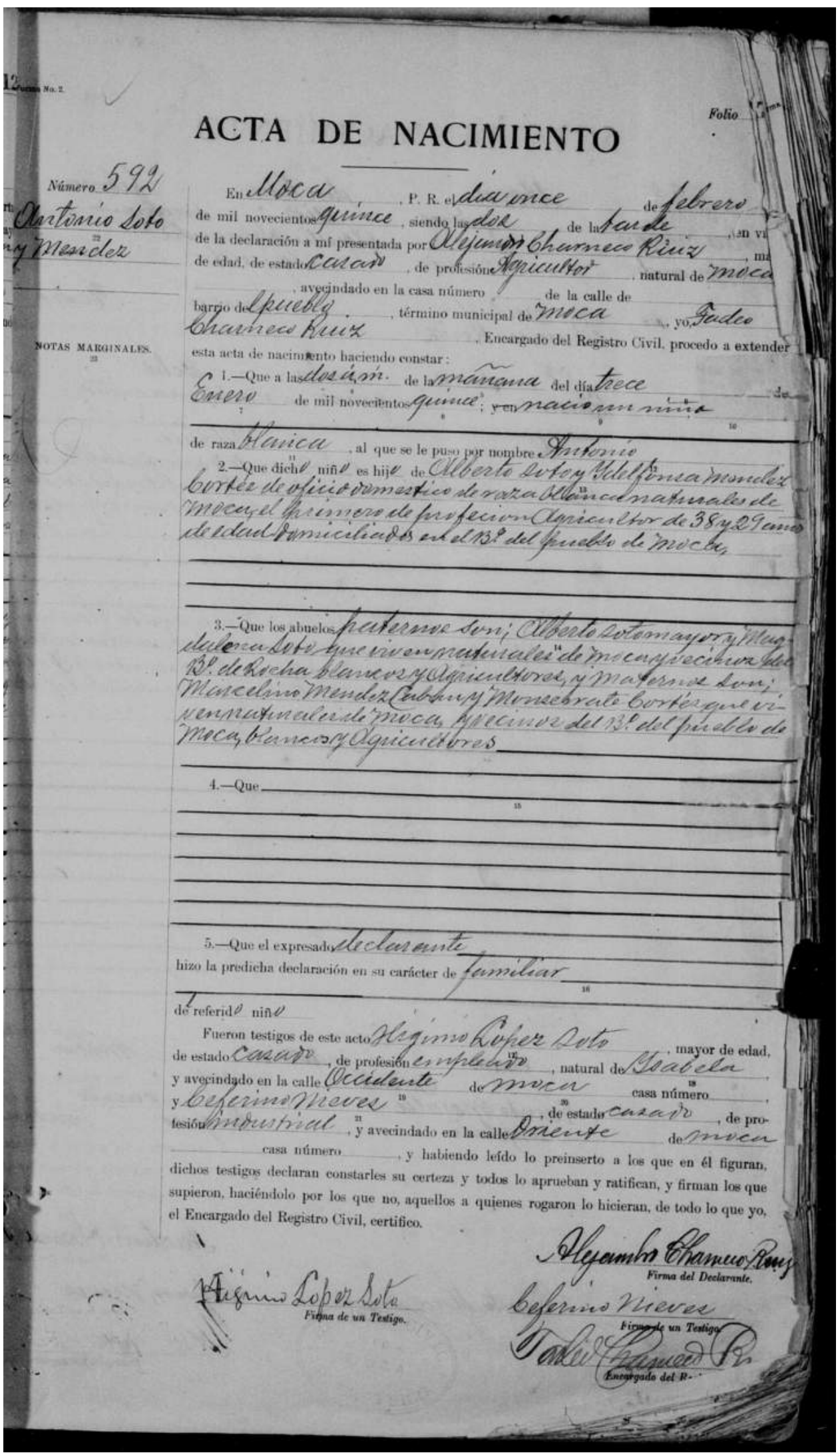

Figure 6. Birth record of my grandfather, Antonio Sotomayor Mendez. 
Germán had one hundred vecinos (socially recognized landowning heads of households), Arecibo seventy-three, and Coamo one hundred. ${ }^{25}$ These numbers are probably an underestimate, given that recently discovered documents indicate that Aguada by 1700 had 221 vecinos (or militia soldiers), which multiplied by seven (the number of individuals per vecino) gives us 1,547. These numbers are based on the militia muster rolls, to which our Sotomayors belonged (as did the Colóns). Priests were vigilant in examining blood purity and kinship relations in order to marry according to ecclesiastical doctrine. It is probable that in 1821 there were more parish records that could trace Don Lorenzo de Sotomayor's ancestors back to the mid seventeenth century.

The Sotomayor family in Puerto Rico's north-west commonly used the surname Soto. This is not uncommon and also occurred in the Iberian Peninsula since the lineage's origins in the twelfth century. Many of the early Sotomayors in Galicia appear in documents as Paio Mendez, Alvaro Páez, Pedro Álvarez, Suero Álvarez, etc. The standardization of surnames as an exclusive patriarchal identity practice solidified after the eighteenth century, ${ }^{26,27,28}$ and the consistent use of spelling as late as the twentieth. In 1487, the Clavero [knight in charge of a castle; one of the seven highest military ranks] of the Order of Alcantara, Don Francisco de Sotomayor, filed his last will and testament in the village of La Rambla in Cordoba, declaring that:

I, Don Francisco de Sotomayor, Clabero [sic] of the Order of Alcantara, vezino [sic] of the city of Salamanca ... instruct that my quinto inherited from Mosen Soto, my father, let it be known that all of it be distributed equally among my son Juan de Soto and my brothers. I instruct that Juan de Soto, my brother, receives five thousands maravedis....$^{29}$

In Jerez de la Frontera in the seventeenth century, Garci Méndez de Sotomayor (namesake of the Lord of El Carpio) was also known as Garci de Soto. ${ }^{30}$ Recently, a Spanish genealogist stated that "we all know that the Sotomayor are referred to in many writings and documents just as Soto." ${ }^{31}$ Puerto Rican testaments and birth records from the nineteenth century show the spelling of members of the Sotomayor family as Soto=mayor, Soto Mayor, Soto mayor, Soto-mayor, or Soto Maior, among others. The use of Soto and Soto Mayor was used randomly in Puerto Rico's north-west towns to the extent of one person appearing in the same document with the variations Soto, Soto Mayor and Sotomayor.

The first Sotomayor in Puerto Rico was Don Cristóbal de Sotomayor, youngest son of Don Pedro Álvarez de Sotomayor, Count of Caminha (Portugal) and Lord of Soutomaior (Galicia) and Doña Teresa de Távora. Don Cristóbal, along with other siblings, renounced his rights over the Castle of Sotomayor in order to concentrate the lineage's wealth in mayorazgo [the right to the enjoyment of property on condition that it is to pass, perpetually, successively to the eldest son] in the firstborn sibling, Álvaro Páez de Sotomayor. ${ }^{32}$ After renouncing this estate, Don Cristóbal set sail to the New World, particularly the island of Puerto Rico. He was twenty-three in 1509 when he arrived there. However, Don Cristóbal, his nephew or cousin Don Diego de Sotomayor, and four other Spaniards died in 1511 in an ambush near the current town of Aguada when the Taínos rebelled against the Spanish. The village of Sotomayor (today Aguada) was attacked by the cacique [leader] Guarionex, starting an ill-fated attempt to regain control of their island. A Royal Decree from March 21, 1515 indicates that Don Cristóbal's son, Don Pedro de Sotomayor, would inherit his belongings. ${ }^{33}$ However, we have not been able to document this Don Pedro in any other primary document. António Pedro de Sottomayor believes the letter was falsified by Don Cristóbal's uncle, Don Pedro de Sotomayor, after he was in exile in Portugal having ordered the murder of his mother, Inés Enríquez de Monroy, who had married his sister to a nobleman from a rival lineage. ${ }^{34}$

Another branch of the Sotomayor family in Puerto Rico, from El Carpio (Córdoba), was also on the island early in the colonization. In 1511, Don Luis de Sotomayor received an encomienda [grant conferring the right to demand tribute and forced labour from the inhabitants] in Puerto Rico. ${ }^{35}$ The Royal Decree from Catholic King Fernando said that "his father and relatives are my servants." ${ }^{36}$ Servants in this case meant military service. This Don Luis de Sotomayor from 1511 was Don Luis Álvarez de Sotomayor (born c.1485), a captain in the conquest of Orán in 1509 and mayor of the Rosalcazar and Mazalquivir fortresses. ${ }^{37}$ His relatives also served the king: his father Don F(H)ernando Álvarez de Sotomayor was mayor of Colomera, uncle Don Pedro Álvarez de Sotomayor mayor of Colomera, grandfather Don Gil Hernández de Sotomayor was mayor of the Alcázar de Córdoba, mayor of the Priego and Rambla castles, and Knight of the Band, cousin Don Pedro Fernández de Alcaraz Sotomayor was regidor [council member] of Alcalá la Real and mayor of Colomera. ${ }^{38}$ It is relevant to note that his grandfather, Don Gil, was mayor of the Real Alcázar de Córdoba, or the Castle of the Catholic Monarchs. The Catholic monarchs Isabel and Fernando lived in this castle for eight years during the planning stages of the conquest of Granada and it was here where they granted Christopher Columbus a meeting seeking support for his exploration trip to the Indies (in 1486). Therefore, King Fernando rewarded a grandson of the mayor of his castle in Córdoba with an encomienda in the newly "discovered" island of San Juan de Puerto Rico. Don Luis died serving as captain in Mazalquivir in 1558.

Don Luis de Sotomayor was another Sotomayor in Puerto Rico during the sixteenth century, who in 1561 belonged to a group of vecinos that asked the governor to defend the island against Carib attacks. This Don Luis was the son of the one that received the encomienda in 1511 and by 1561 served as artillery captain, eventually dying in 1587, probably in Mazalquivir. ${ }^{39}$ The fact that this Don Luis appeared as vecino indicates that he had residence and owned property in Puerto Rico, and enjoyed recognition within the city, probably inherited, like his title Don, from 
his father. It was normal as well for this social class to have property in various places, especially those in the military who were often in transit. Finally, another Don Luis de Sotomayor asked in 1619 for a post in "the Indies" appropriate for his "stature and services." ${ }^{40}$ We don't know if he ever reached the Indies, which could have been Puerto Rico, given that soon after this request he was made Governor of Melilla. Despite the fact that this family had such successive roles, properties, and interests in Puerto Rico, we don't know of any descendant of the last Don Luis de Sotomayor in Puerto Rico. His two known sons with his first wife, Doña Bernardina de Navarrete, Luis and Juan, died in battle in Melilla in 1649. ${ }^{41}$ His son, Don Luis de Sotomayor y Pérez de Navarrete, submitted a record of merit in 1643 seeking admission to the Order of Santiago and provided his genealogical tree and other pertinent information. ${ }^{42}$

The third Sotomayor in Puerto Rico during the sixteenth century was Doña Isabel de Sotomayor, daughter of regidor perpetuo [permanent council member] Hernán Pérez de Valenzuela and Doña María del Rincón. She was a paternal granddaughter of Alonso de Lepe and Catalina Pérez de Valenzuela and a maternal granddaughter of Martín del Rincón and Catalina Pérez. Doña Isabel married Captain Pedro Mexía de Lugo, born in Tenerife, Canary Islands, in the mid to late 1500s in San Juan and had three sons, Captain Juan de Lugo Sotomayor, Captain Guillermo de Lugo Figueroa, and Captain Diego de Figueroa Lugo. Most probably Isabel's Sotomayor surname came from her paternal grandmother, Catalina Pérez de Valenzuela from Huelva and from the Sotomayors from Extremadura. This family in particular shows how in Spain, especially in the fifteenth, sixteenth, and seventeenth centuries, surnames were envisioned holistically, not strictly paternally, and many surnames were taken from mothers, grandmothers, or great-grandmothers without offending the paternal lineage. ${ }^{43}$

\section{Ancestors of the Sotomayors and Colóns from Aguada: genealogy and genetics}

\section{A brief introduction to genetics}

In order to understand the ancestors of Juan de Sotomayor from Aguada it is imperative to keep in mind the genetic data. Today, we use genetics to study genealogies that lack documentation. At the same time, genetics would not work without genealogies to support it and give it meaning. The field of genetic genealogy is well established and it is considered a scientific methodology in its own right, which has had its own academic journal since 2005 (the Journal of Genetic Genealogy), and a recognized association, the International Society of Genetic Genealogy (ISOGG). ${ }^{44}$ Puerto Rican genetic genealogist Ana Oquendo Pabón is one of the pioneers in this field in Puerto Rico. ${ }^{45}$ Thanks to this methodology, our genetic results provide us with important evidence to make some key genealogical arguments that would not have been possible otherwise. Moreover, the genetic match in question, which involves two different surnames at the edge of genealogical time (sixteenth century), is so far one of the few, if not the only one, known in the academic literature. ${ }^{46}$

The $Y$ chromosome is inherited solely by males, father to son, then to sons, grandsons, etc. The inheritance of the $Y$ chromosome among males mimics the social pattern of surnames in most European societies and, as such, it can be of great use for genetic genealogy. ${ }^{47}$ The sequences within the $Y$ chromosome that repeat in a mostly stable manner are called short tandem repeat or STRs. STRs are inherited from generation to generation almost unaltered. However, a mutation can occur during this transmission. The more mutations between two men, the more distant their ancestor in common. Genetic distance (GD) is the amount of mutations in the comparison of STRs in two men. Therefore, two men that have identical STRs at 37 markers have a closer ancestor in common than two men that match 35 of 37 markers, with a 33 of 37 match being further apart. ${ }^{48,49}$

The best-known commercial company to study the $Y$ chromosome for genealogical purposes is Family Tree DNA (FTDNA). They offer various levels of tests depending on how many markers are tested. STRs can be studied by markers. FTDNA offer tests for 12, 37, 67, and 111 markers, plus the Big Y-500. Given that the STRs mutate frequently (in the larger scheme of human evolution) it is best to study as many markers as possible to establish a relationship within a genealogical time frame. As a minimum, the 37-marker test is recommended in order to obtain better precision in the genetic relationship in the $Y$ chromosome between two men. But the tests at 67 and 111 markers offer better results, in other words, more precision within a genealogical time frame. The gold standard and the most precise in the market to study the $Y$ chromosome is the Big Y-500.

The other way to study our DNA is through the single-nucleotide polymorphisms or SNPs. Basically, when we study SNPs we look for mutations in the nucleotides ( $A, T, C$, and $G$ ) in the $Y$ chromosome. These SNPs are passed down from father to son and allow us to see which SNPs are similar among two men. Like the STRs, the more matching SNPs between two men, the closer they are related. These SNPs can be grouped and organized to create haplogroups (also known as subclades). The organization of haplogroups can provide ideas of ancient ancestry. ${ }^{50}$

\section{The genetic results}

There are several Y-DNA matches between members of the Sotomayor and Colón families in Puerto Rico (see Table 1). These results include three men with the surname Sotomayor and two men with the surname Colón, for a total of five men matching in the $Y$ chromosome. The 
Table 1. Sotomayor-Colón Y chromosome matches with genetic distance.

\begin{tabular}{lcccc}
\hline Markers & Gerry Sotomayor & Jaime Sotomayor & Moisés Colón & Edwin Colón \\
\hline Antonio Sotomayor at 37 & 1 & 1 & 2 \\
Antonio Sotomayor at 67 & 1 & 1 & 2 \\
Antonio Sotomayor at 111 & 1 & 2 & 4 \\
\hline
\end{tabular}

three men with the surname Sotomayor match at 111 markers, but with differences according to FTDNA's Time Predictor (TiP) tool. TiP predicts a $95.31 \%$ probability of Gerardo "Gerry" Sotomayor sharing a common ancestor with me within four generations, $99.78 \%$ within eight generations, and $99.99 \%$ within twelve generations. Gerry and I share 110 out of 111 markers $(111, G D=1)$, and our ancestor in common was Don Juan de la Cruz de Sotomayor who lived between 1818 and 1862 (Gerry is my third cousin once removed). The second Sotomayor $Y$ chromosome match was Jaime Sotomayor. TiP predicts an $85.19 \%$ probability of Jaime sharing a common ancestor with me within four generations, $98.82 \%$ within eight generations, and 99.92\% within twelve generations. Jaime and I share 109 out of 111 markers (111, GD = 2), and our ancestor in common was Juan de Sotomayor who lived between c.1740 and c.1800 (Jaime is my fifth cousin once removed). Gerry and I have a closer GD than Jaime and I. Both the TiP and markers matching between us reflect the actual genealogical relationship.

Our matches with the Colón men are not supported by documented genealogies, but do offer important genetic data with implications for genealogical arguments. TiP predicts an $89.79 \%$ probability of Moisés Colón sharing a common ancestor with me within four generations, $98.96 \%$ within eight generations, and $99.89 \%$ within twelve generations. We match 65 of 67 markers $(67, G D=2)$, but there is no identified genealogical connection. We don't have data to compare at 67 and 111 markers with Edwin Colón, only 37 markers. At this level, TiP predicts a $29.87 \%$ probability of Edwin sharing a common ancestor with me within four generations, $69.87 \%$ within eight generations, $89.87 \%$ within twelve generations, and $97.03 \%$ within sixteen generations. We match 33 out of 37 markers, for a GD of 4 . This GD at 37 markers is particularly relevant when we compare it with the three Sotomayor men in the sample. My matches at 37 markers with both Jaime and Gerry Sotomayor have a GD of 1, and with Moisés Colón of 2. Given that my Most Recent Common Ancestor (MRCA) with Jaime dates from 1740, we can assume that my match with Moisés Colón is older than 1740 (possibly in the mid 1600s), and my match with Edwin Colón is significantly older (possibly in the mid 1500s) (see Table 2).

Table 2. Sotomayor-Colón TiP comparison at 37 markers.

\begin{tabular}{|c|c|c|c|c|}
\hline MRCA within ... & Gerry Sotomayor & Jaime Sotomayor & Moisés Colón & Edwin Colón \\
\hline Antonio Sotomayor - 4 generations & $83.49 \%$ & $83.49 \%$ & $83.49 \%$ & $29.87 \%$ \\
\hline Antonio Sotomayor - 8 generations & $97.28 \%$ & $97.28 \%$ & $97.28 \%$ & $69.87 \%$ \\
\hline Antonio Sotomayor - 12 generations & $99.55 \%$ & $99.55 \%$ & $99.55 \%$ & $89.87 \%$ \\
\hline Antonio Sotomayor - 16 generations & $99.93 \%$ & $99.93 \%$ & $99.93 \%$ & $97.03 \%$ \\
\hline
\end{tabular}

Edwin Colón's Big Y-500 results confirmed the date range of our Time to Most Recent Common Ancestor (TMRCA) of 400 to 600 years ago. Larry Walker, co-administrator for the FTDNA R-DF41/R-CTS2501 group, did a preliminary examination of the data:

I did a manual comparison of your results and Edwin's results based on what data is available to me through FTDNA's GAP tools. My preliminary estimate is: You and Edwin share a block of 21 build38 [sic] SNPs. I guestimate that the oldest of these shared SNPs formed about 3100 (3900-2300) YBP, and the TMRCA for you and Edwin is about 550 (650-400) YBP. Your shared build38 SNPs are:

10023284 C $>A[A 1750]$

12189428 A $>G[A 1752]$

12709187 C $>A$ [A1754]

13609673 C $>A$ [A1755]

15025685 A $>C$ [A1756]

$15609750 \mathrm{G}>\mathrm{A}$ [A1757]

15779266 A $>G$ [A1758]

$15997517 \mathrm{G}>\mathrm{C}$ [A1760]

16280849 C $>$ T [A1762]

$16558448 \mathrm{~T}>\mathrm{C}[\mathrm{A} 1763]$

$20350450 \mathrm{G}>A$ [BY33879]

20489820 T>G [A1766]

$21160665 \mathrm{~T}>\mathrm{C}[\mathrm{A} 1767]$ 


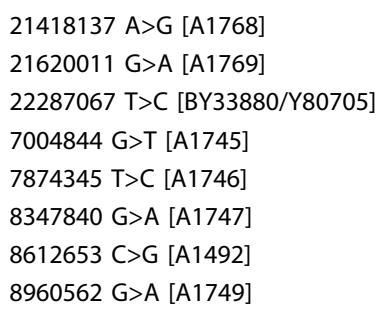

This will all change when you get a more complete analysis by YFull and the Big Tree, but I should be someplace within the ball park." ${ }^{51}$

The other result of relevance in this study of the Y chromosome pertains to the SNPs, which are organized into haplogroups or subclades. A very common haplogroup in Iberia is the R1b-DF27, which is a subclade of M269 and has higher frequencies among Basques, but possibly originating in north-east Spain. ${ }^{52}$ The Sotomayor and Colón men from this study had positive results for the DF41 haplogroup, which is a downstream subclade of the L21 haplogroup, which in turn is downstream from M269. Mathematician and data analyst Joe Flood has concluded that the L21 haplogroup originated in south-west Britain some 4,500 years ago as part of the Beaker Atlantic culture. ${ }^{53}$ The L21 haplogroup has a higher frequency in Brittany (France), southern England, and Galicia (Spain). ${ }^{54}$ Although the DF41 haplogroup has not been academically researched, its members so far have ancestral origins almost exclusively in places popularly associated with "Celtic" identities, including Ireland, Scotland, Isle of Man, Wales, Cornwall/Devon, Cumbria, Galicia/northern Portugal. (On the creation of a "Celtic myth" of the late twentieth century, especially through music, which went beyond archeological perspectives, see Javier Campos Calvo-Sotelo's article in Popular Music and Society. ${ }^{55}$ ) Some branches of the DF41 haplogroup (L744, L781) descend from Walter Fitz Alan (1110-1177) who was appointed High Steward of Scotland under King David I of Scotland, and are popularly known as the "Royal Stewart" haplogroups. There are a few men within the DF41 subclade that have lberian ancestry. While most do not have genealogical data beyond genealogical time frames, one of them does have genealogical data of relevance to this study. Rodolfo Hernández Chávez, from Mexico, also had positive results for the DF41 subclade. His direct male ancestry goes back to the Fernández de Córdoba lineage, a famous lineage of Galician origin in the twelfth century that originally used the surname Fernández de Temes, ${ }^{56,57}$ fitting the geographical distribution of both L21 and DF41 subclades. Taking these SNP results into consideration, the patrilineal ancestry of our Sotomayors and Colóns most probably came from the north-west of the lberian Peninsula. Our Big Y-500 test allowed for the creation of a new Puerto Rican haplogroup in FTDNA called R-BY33880. (In YFull the name for BY33880 is Y80705.)

Genetic results also indicate that Don Cristóbal de Sotomayor was not the direct paternal ancestor of our Sotomayor and Colón men. In a recent academic archeo-genetic study, our Y-DNA was compared with the Y-DNA of Don Cristóbal's uncle, Don Álvaro Páez de Sotomayor, who rests in the cathedral of Tui. ${ }^{58,59}$ The result of this study was negative. ${ }^{60}$ Given that the three Don Luis de Sotomayors in Puerto Rico in the sixteenth century descended agnatically from Mem Páez Sorredea, they would not be the direct agnatic ancestors of the Sotomayors and Colóns in this study. Therefore, we are before an event where a son inherited the surname from a maternal source.

\section{Interpretation}

Exhaustive historical research over the last five years on the possible marriage or union between the Sotomayor and Colón families of the sixteenth century or earlier that fit the military profile of the ones in Puerto Rico led to very little success. (My research on the Sotomayor family throughout the Spanish-speaking world spans over fifteen years.) A good clue was Don Luis de Sotomayor, Governor of Melilla, and his second wife Doña Petronila Colón de Toledo, both from Orán (present-day Algeria), at the end of the sixteenth century. Although the family of Don Luis had connections with Puerto Rico, this couple did not have children, so they were eliminated as an alternative. ${ }^{61}$ With very few options in terms of families with the combined surnames Sotomayor and Colón in Puerto Rico, the Lugo Sotomayor family from Puerto Rico from the late sixteenth and early seventeenth centuries merited closer study. The Lugo Sotomayor family is the result of the marriage between Captain Pedro Mexía de Lugo and Doña Isabel de Sotomayor. Captain Pedro Mexía de Lugo, born in 1543 (he declares being forty years old in $1583^{62}$ ) descended from the conquistadors of the Canary Islands and 
was a close relative of the adelantado [governor] Alonso Fernández de Lugo. Their children were Captain Juan de Lugo Sotomayor, Doña Isabel de Lugo Sotomayor, ${ }^{63}$ Captain Diego de Figueroa Lugo, and Captain Guillermo de Lugo Figueroa Buenaventura. (Captain Diego de Figueroa de Lugo was named as uncle of Clara de Lugo Figueroa, daughter of Captain Guillermo de Lugo Figueroa in the will of Lazaro Ramirez de Arellano: “Y para cumplir $y$ pagar este mi testamento mandas y gastos en el contenidas dejo nombro por mis albaceas y testamentarios al capitán Diego de Figueroa de Lugo, tio de mi mujer." ${ }^{\prime \prime 4}$ ) Captain Juan married Doña Luisa Velázquez, daughter of Captain Baltazar Velázquez and Doña Juana Bautista, and together they had the following children: Captain Juan de Lugo Sotomayor, Captain Francisco de Lugo Sotomayor, Doña María de Lugo Sotomayor (who married Don Agustín de Cuadros and had, among others, a son who would become the priest Don Félix de Cuadros ${ }^{65}$ ), Doña Isabel de Lugo Sotomayor, Doña Francisca de Lugo Sotomayor, Doña Luisa Juana de Lugo Sotomayor, Doña Ana de Lugo Sotomayor, and probably Doña Marina de Lugo Sotomayor. ${ }^{66}$ (The marriage of Alférez José de Ávila de las Cuebas, legitimate son of Don José and Doña Ana de las Cuebas, from Jeréz de la Frontera, and Doña Josefa de Espinosa de los Olivos y Lancebo y Lugo, legitimate daughter of Capitán Don Alonso de Espinosa de los Olivos y Lancebo and Doña Mariana de Lugo y Sotomayor was recorded on January 24, 1693. The witnesses were Antonio de Benavides and Captain Juan de Lugo y Sotomayor.)

Of these children, Captain Juan married Doña Ana de Avendaño on November 16, 1665 at the Cathedral of San Juan. She was the daughter of San Juan's regidor perpetuo Don Andrés Montañez Mercal and Doña Bárbara de Villela. ${ }^{67}$ Captain Francisco married Doña Gerónima Muxica Negrete also at the Cathedral of San Juan on June 18, 1668. She was the daughter of Captain Cristóbal Muxica and Doña Gerónima Negrete. ${ }^{68}$ By 1673, Juan and Ana had three daughters, Mayora, Benedicta, and Juana Sebastiana. They lived, together with Juan's siblings Francisco and Francisca, at \#149 San Cristóbal Street in San Juan and owned ten slaves. ${ }^{69}$ I will return to this family later.

We do not have more information about Captain Diego de Figueroa Lugo. But the other son of Captain Pedro and Doña Isabel, Captain Guillermo de Lugo Figueroa, married Doña Leonor García (or Ruiz) de Vargas and had - among other children - Captain Andrés de Lugo Figueroa and Doña Clara de Lugo Figueroa. ${ }^{70}$ (Application of grace (merced) by Captain Antonio Ramírez de Arellano, husband of Clara de [Lugo] Figueroa indicating that Andrés de [Lugo] Figueroa was his uncle. All of them - Andrés, Clara and their parents Guillermo de Lugo Figueroa and Leonora de Vargas - are mentioned as being "Noble People and Principal Old Christians" [Gente Noble y Principales xstianos Viejos].) ${ }^{71}$ Captain Andrés married Doña Clemencia Ramos Colón de Luyando, daughter of Captain Diego Ramos Colón de Luyando and Doña Juana Díaz de Sandoval. Captain Andrés and Doña Clemencia had a son named Captain Josef Ramos Colón, born c.1665. Captain Josef Ramos Colón married Doña María de Benavides and had among other children - Captain Gerónimo Ramos Colón, who married Doña Jacinta de Mirabal y Segarra on March 19, 1708 in Aguada. Don Gerónimo and Doña Jacinta had the following children: Juan Ramos Colón, María Ramos Colón, Miguel Ramos Colón, and José Ramos Colón. ${ }^{72}$ As we can see, the descendants of Captain Andrés de Lugo Figueroa and Doña Clemencia Ramos Colón used the surname Ramos Colón (see Figure 7). More importantly, Don Gerónimo and Doña Jacinta married in Aguada. Therefore, Captain Pedro Mexía de Lugo and Doña Isabel de Sotomayor had two parallel lines of male descendants that used the surnames Sotomayor and Colón by the end of the seventeenth and early eighteenth centuries in San Germán and Aguada, just at the same time and place where our Sotomayor and Colón ancestors show up. Let us consider as well that in the

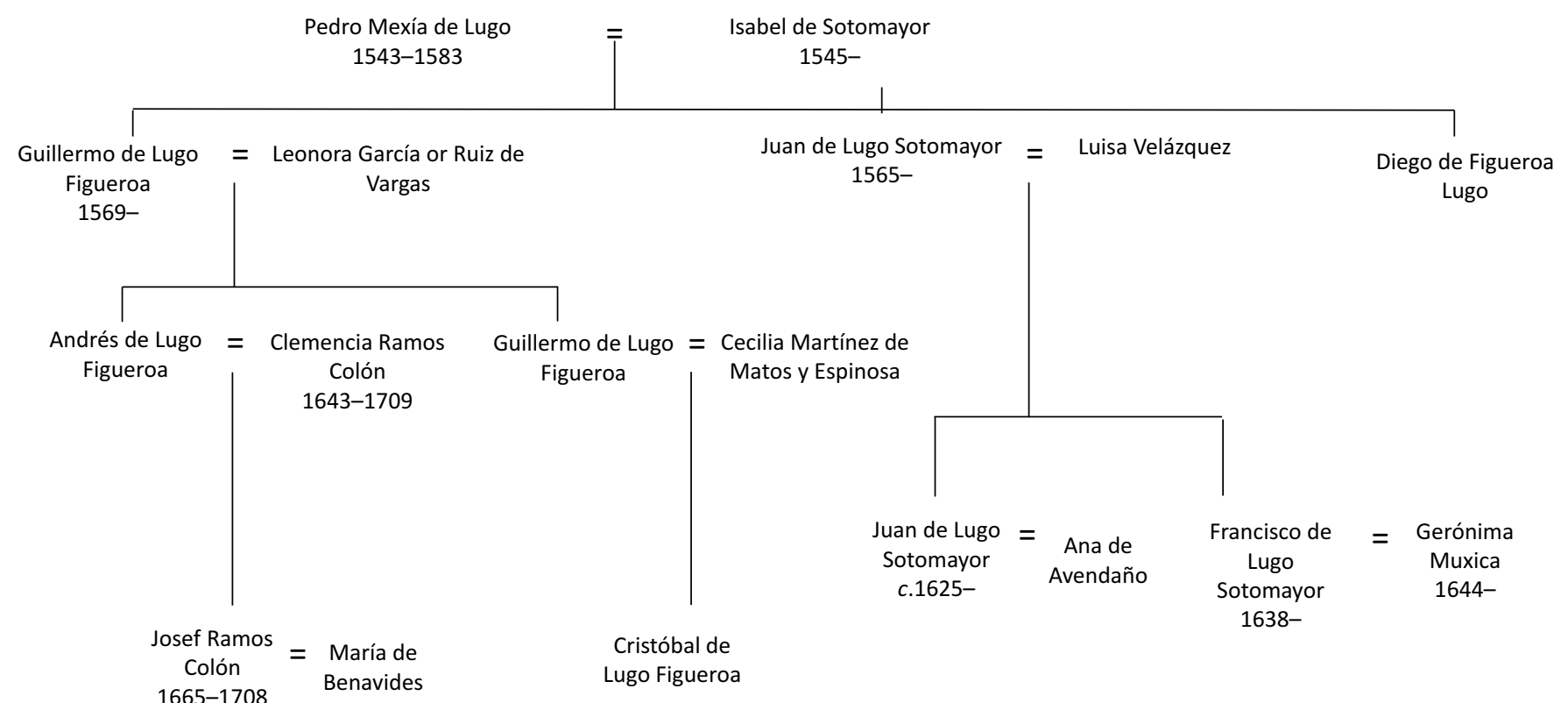

Figure 7. Descendants of Captain Pedro Mexía de Lugo. 
seventeenth century these Lugo Sotomayors also appear in the documentation as Sotomayor only, without Lugo, and vice versa, showing the anthroponymy practice that allowed for the inheritance of maternal surnames in the conceptualization of lineage and family. In 1646 we see Captain Juan de Sotomayor receiving salt from Alférez Melchor Pérez Cerrato to take in his frigate to the ports of Coamo and San Germán to house in the royal warehouse. ${ }^{73}$ Juan de Sotomayor appears as such in 1688 in the records of the San Juan cabildo [administrative council] as part of a group of gentlemen supporting the work of Gaspar Martínez. ${ }^{74}$ Luisa Juana de Lugo Sotomayor appears as Luisa de Sotomayor in the records of the San Juan cabildo in 1684 as part of a group of ladies protesting the government of Juan de Robles Lorenzana. ${ }^{75}$ The date of these families' ancestor in common is the end of the sixteenth century, corresponding with the estimate of the genetic match between our Sotomayor and Colón families from Moca/Aguada, Puerto Rico.

I have good clues that connect this seventeenth-century (Ramos) Colón family to Edwin Colón's most distant documented ancestor Antonio Colón Santiago, born c.1800 in Moca, who appears as Second Corporal in Moca's urban militias in $1819 .^{76}$ The clue comes from a Moca family that used the compound surname Colón de Santiago. Second Corporal Antonio was married to María del Rosario López and had at least two sons, Manuel Jesús and Marcelino Colón López (Edwin's direct ancestor). ${ }^{77}$ It looks as though the couple also had another son named Francisco Colón y López, who died on August 29, 1890 at fifty-five years old in Adjuntas. ${ }^{78}$ This death record from Adjuntas says that Francisco was a son of Antonio Colón y Salas, from the town of Manatí, and María Rosario López Hernández, from San Sebastián. I think this record shows that Edwin's ancestor "Antonio Colón Santiago" was indeed a son of Antonio Colón de Santiago y Salas and María Velázquez Rodríguez, who married in Moca on August 7, 1798. ${ }^{79}$ The person declaring Francisco's death made the mistake of saying that Antonio was born in Manatí, when he was actually born in Moca (such mistakes are not uncommon; my grandfather's marriage record from 1940 says that he was born in Humacao, when in fact he was born in Moca in 1913). This person took out the surname Santiago, replacing it with the grandfather's surname Salas, including again an ancestral maternal surname. This, added to his wife's name, María del Rosario López, is revealing. I haven't found any other Colón Salas couples at this time and in these towns, and certainly no couple named Antonio Colón and María Rosario López. Additionally, according to Francisco Colón López's death record, his children with Guadalupe Cuevas y González were named Marcelino (for his uncle and Edwin's ancestor), Marcos, Antonio (for his grandfather) and Victoria (for her great-grandmother?). We also know that Francisco's aunt was named Francisca Colón Velázquez. She died on September 15, 1886 in Moca without descendants. ${ }^{80}$ The onomastic pattern and chain within this family is clear.

We know more about Antonio Colón de Santiago y Salas (thus, Marcelino Colón's grandfather). He appears as retired from Moca's urban militias in 1817 and was the son of Cristóbal Colón de Santiago (born c.1750 and retired from the urban militias in $1817^{81}$ ) and Victoria de Salas Hernández, who married on December 30, $1776 .^{82}$ Cristóbal was in turn the son of Cristóbal Colón de Santiago (born probably c.1720) and Juana González. This family was from San Sebastián (originally a barrio [neighborhood] of Aguada), but had property and moved constantly throughout the region. There are a few options for the possible parents for this last Cristóbal, but there is one that is particularly interesting. The godparents listed in the baptism record for Marcos Colón de Bonilla, legitimate son of Diego Colón and María Isabel de Bonilla, from May 9, 1714 in Coamo, were Cristóbal Colón and Doña Isabel de Santiago y Rivera. ${ }^{83}$ The onomastic chain, the surnames, and the dates strongly suggest that this couple might be the parents of the Colón de Santiago family from Aguada and Moca in the eighteenth century. This couple does not appear in any of the surviving parish records from Coamo during the eighteenth century (according to the transcriptions by Jose Bello in the group "Genealogías de las Familias Ramírez de Arellano en Puerto Rico," from May 29, 2018), or San Germán, ${ }^{84}$ which leads me to believe that they left for Aguada, where no parish records exist for the eighteenth century.

If the paternal ancestors of Edwin Colón go back to c.1720 and the Ramos Colóns reach the end of the seventeenth century, we are only looking for one generation to fill the gap. If we use the generational age of thirty years, ${ }^{85}$ this Cristóbal Colón would have been born c.1690, placing him in the same date range as the children of Captain Josef Ramos Colón and Doña María de Benavides: Catalina (1680), María (1688), Gerónimo (1685), and Margarita (1692). We know that Gerónimo married Doña Jacinta de Mirabal y Segarra on March 19, 1708 in Aguada. (Gerónimo was alcalde ordinario [magistrate] of San Germán. ${ }^{86}$ ) Perhaps his "brother" Cristóbal did the same with Doña Isabel de Santiago y Rivera in Aguada. This proposition is not that illogical, given that there were various high-ranking militia officers with the surname Santiago in Aguada by 1700: Don José de Santiago (born 1671) was sargento mayor in Aguada, had properties and was the founder of the town of Añasco in 1728; ${ }^{87}$ Antonio de Santiago was sixty-five in 1709 and lived in Aguada; Francisco de Santiago was fifty-eight in 1709 and was owner of a few hatos [herds of pigs] in Olgadero and Añasco; Juan de Santiago was twenty-six in 1709 and had properties in Olgadero; Francisco de Santiago was twenty-three in 1711 and had a country house in Espinal. ${ }^{88,89}$ Also in the militia muster rolls was Cristóbal de Santiago, born in 1660, sergeant and ayudante [military assistant] in Aguada, and a member of the Holy Brotherhood of San Germán. ${ }^{90}$

I feel equally (or more) comfortable in establishing the genealogical connections of the Sotomayor side. Let us remember that my most distant documented ancestor is Juan de Soto Hernández, who was born c.1700 in Aguada and died in 1791 in Moca. Given that there are no existing parish records for the north-western towns, particularly for Aguada and Moca, for most of the eighteenth century, we must resort to other alternatives. Historian David Stark has suggested that an alternative for genealogical studies can be the urban militia muster rolls. During the time 
period under study, all able men were obliged to serve in the urban militias, ${ }^{91}$ so these muster rolls can be a good source to find men, and act as a sort of census. ${ }^{92}$ Andrés Méndez Muñoz's publication of the 1699 and 1700 urban militia muster rolls are thus of great importance. ${ }^{93,94,95,96}$ There were a few officers with the compound surname Soto de las Cuevas in these lists, who have not yet been identified. For the Sotomayor in question, these men can be discarded because there are no men with the surname Cuevas in the well-developed genealogies of the Lugo Sotomayor or the Ramos Colón families before 1645 (birth date of Captain Manuel de Soto de las Cuevas, older of the Soto de las Cuevas men). With these officers out of consideration, we are left with a few men with the surname Soto in Aguada: Juan Francisco de Soto (born in 1679), Francisco de Soto, Patricio de Soto (1687) and Fernando de Soto (no men appeared as Sotomayor, which, as indicated above, was the normal practice in Aguada). There is a high degree of probability that the missing link in the Sotomayor genealogy is Juan Francisco de Soto, who was literate and had possessions in the hato of Moca in 1707, thus being one of the few early landowners in Moca at that time. ${ }^{97}$ Also in these lists in Aguada was Guillermo de Lugo, and in another list we see a Captain Guillermo de Lugo y Buenaventura, probably a grandson or great-grandson of Captain Guillermo de Lugo Figueroa y Buenaventura, son of Captain Pedro Mexía de Lugo and Doña Isabel de Sotomayor. The gravitation of these families toward Aguada in the seventeenth century illustrates how noble families moved or created new towns in search of lands and growth. Given the date, place, and onomastic chain - Juan Francisco in honor of his father and uncle - his properties in Moca where our Sotomayors were from, that the militia muster rolls were a census, and that a Guillermo de Lugo Buenaventura appears in the region, I propose Juan Francisco as the father of Juan de Soto Hernández, which by this generation had already ceased to use Lugo in the surname. True, the documentation available is isolated and fragmented, but it is interwoven by the genetic results and Puerto Rico's historical context. That is, the genetic evidence, plus these historical facts, allows us to delineate these genealogies. Without the genetic data these historical documents would not make sense, but without the historical documentation these genetic results would not make sense either.

An examination of the urban militias is, in effect, a good source to evaluate these connections in historical context. Another factor to take into account is endogamy. José Eizaguirre has demonstrated that white endogamy in Puerto Rico during the seventeenth century was very strong, being even stronger, practically generalized, in San Germán and Aguada.$^{98}$ We have seen that these families belonged to the urban militias, many were captains and their spouses were daughters of captains or regidores. If Juan Francisco de Soto was a soldier in Aguada's urban militias, it would be normal that his descendants also married other urban militia family members from Aguada. This was the case for all of the children of Juan de Sotomayor and Serafina de Lugo, my 5th-great-grandparents. Their ten children were born in the second half of the eighteenth century and married into families who were also members of the urban militia muster rolls from 1699/1700 (Table 3). These families include Lorenzo de Acevedo, Vélez-Borrero, J(X)iménez, Medina, Luciano de (la) Fuente(s), Pérez de Gerena and Badillo. In fact, there are many more connections, for these families continued intermarrying throughout the nineteenth and twentieth centuries.

Table 3. Children of Don Juan de Sotomayor and Doña Serafina de Lugo.

\begin{tabular}{ll}
\hline Juan de Sotomayor and Serafina de Lugo's children & Spouse \\
\hline 1. Juan Mártir de Sotomayor & María Narcisa Vélez Borrero \\
2. Alberto de Sotomayor & María Dionisia Ximénez y Hernández de Medina \\
3. Gregorio de Sotomayor & a. María Jiménez \\
& b. María Josefa Vera \\
4. Brígida de Sotomayor & Juan Antonio Borrero \\
5. Juan Francisco de Sotomayor & María Badillo \\
6. Eusebio de Sotomayor & Bárbara Pérez de Gerena \\
7. Marcos de Sotomayor & Rosalía Lorenzo de Acevedo \\
8. Alejandro de Sotomayor & María Ynés Francisca Luciano de Fuentes \\
9. Serafina de Sotomayor & Félix Jiménez y Ramos \\
10. Rosa "Rosalía" de Sotomayor & Manuel Jiménez y Ramos \\
\hline
\end{tabular}

So far, the discussion of the results has centered on interpreting the genetic matches between our Sotomayor and Colón men using fragmented genealogical and historical data. While the focus of this analysis is grounded in Puerto Rico, the discussion that follows will go beyond the island and travel back in time and into the lberian Peninsula through an analysis of the SNPs. This last factor in our genetic genealogy anchors the overall argument that strongly suggests that the lberian ancestors of the Sotomayors and Colóns go back to northern Portugal and Galicia, matching traditional genealogies. Our study of the SNPs for a deep understanding of a family's history is not necessarily a pioneer case. Other studies have used SNPs to establish relationships between current families and medieval lineages. ${ }^{99}$ What is truly novel in our case is the fact that the families in question have two different surnames with a TMRCA at the edge of the genealogical time frame.

Captain Pedro Mexía de Lugo's genealogy is included in the multivolume masterpiece Nobiliario y Blasón de Canarias by Francisco Fernández de Béthencourt, ${ }^{100}$ who is considered a pillar of modern Spanish genealogy. ${ }^{101}$ Captain Pedro Mexía de Lugo was a son of Don Juan Benítez Pereira de Lugo and Doña Elvira Mexía de Figueroa. Don Juan Benítez Pereira de Lugo was, in turn, son of Captain Pedro Benítez de Lugo "El Tuerto" and Doña Ana de Lugo, and this Pedro was son of Admiral Don Juan Benítez de Pereira, Lord of Montillos, and Doña Inés de Lugo, sister of the 
adelantado and Conquistador of the Canary Islands, Don Alonso Fernández de Lugo. Admiral Juan Benítez Pereira was son of Don Rui de Pereira "El Bravo," Captain General of both the Spanish and Portuguese fleets and Lord of Montargil. (The "Fondo Familiar Benítez" at the municipal library in Santa Cruz de Tenerife contains the sources for the study of the Benítez Pereira de Lugo lineage in Tenerife. The collection comprises 4,574 legajos [files]. ${ }^{102}$ For a complete genealogy of Pedro Mexía de Lugo and his Pereira and Lugo ancestors, readers should consult the work of de Béthencourt mentioned above.) Captain Rui de Pereira was a direct agnatic descendant of the well-documented Portuguese lineage of Pereira, which goes back to the region of Braga in northern Portugal in the twelfth century (see Figure 8). Don Gonzalo Rodríguez, agnatic ancestor of Captain Pedro Mexía de Lugo, was lord of "Palmeira," ${ }^{103}$ a locality within the present-day Braga district (see Figure 9).

José Augusto de Sottomayor, author of the celebrated Linhagens medievais portuguesas: Genealogias e estratégias (1279-1325), studied the Pereiras within Portuguese aristocracy. In his study, Sottomayor Pizarro situates the Pereiras as a branch of the Trastámaras, along with the Palmeiras, Traba and Tougues lineages. ${ }^{104}$ These four cousin branches descended from the powerful Froilaz/Traba family from Galicia/Asturias, which ruled over Galician lands from the ninth to the eleventh centuries. ${ }^{105,106}$ This region, which covered northern Portugal, Galicia, and Asturias, has been associated with Celtic culture. A discussion about the problems with the Celticization of the lberian Peninsula is beyond the scope of this article. However, it is interesting to note that the DF41 SNP matches of the Pereira ancestors of the Sotomayors and Colóns so far in FTDNA have ancestry in other places with strong Celtic identity. This is not to say that the DF41 haplogroup in our case proves the Celticness of Galicians/northern Portuguese, given that there are other Iberian men in other L21 "Celtic" subclades. It is not the intention of this article to confuse genetics with culture, just to observe a correlation of peoples and geographies.

As mentioned earlier, a member of the DF41 haplogroup is a man with patrilineal ancestry to another Galician family, the Fernández de Córdoba/Temes. Rodolfo H. Hernández Chávez, an architect and municipal chronicler from Encarnación de Díaz, Jalisco, Mexico, descends agnatically from the Fernández de Córdoba family, which in turn descend agnatically from the Fernández de Temes, who were also descendants from the Froilaz/Traba family. ${ }^{107}$ That is, Rodolfo Hernández's patrilineal genealogy goes back to Don Pedro Froilaz de Traba, who was a brother of Admiral Don Rodrigo Froilaz, and as such, uncle of Don Gonzalo Rodríguez da Palmeira. This means that a third genealogy in our study, that of the Fernández de Temes, links with the Pereiras on paper and genetically. On paper, the ancestor in common between the Pereiras and the Fernández de Temes would be Count Don Froila Bermúdez, who lived between c.1045 and 1091 (see Figure 10), a ricohombre and aristocrat of particular significance during the reigns of Kings Fernando of León, García of Galicia, and Alfonso VI of León. Count Froila had, with Doña Elvira de Faro, Don Pedro Froilaz de Traba (later Temes in León/Spain) and Don Rodrigo Froilaz (later Pereira in Portugal), and together, these cousin branches of the Traba family evidence the "transborder" characteristic of medieval Portuguese and Spanish aristocracy. ${ }^{108}$ Nonetheless, there is a small problem with this connection. The genealogy of both the Fernández de Temes and Pereira lineages indicate that their ancestor in common lived in the eleventh century, one thousand years ago. However, the SNP match between the Pereiras and the Fernández de Temes places the TMRCA some 4,000 years ago. More research is needed to clarify this dissonance. Taking into consideration all the analysis presented in this article, Figure 11 allow us to see my overarching genetic-genealogical argument.

\section{Possible maternal ancestors of Hernán Pérez de Valenzuela: in search of the Valenzuelas and Sotomayors}

It is not clear who the Sotomayor ancestor of Doña Isabel de Sotomayor was. In this section I offer some ideas, which will evidence again the importance of inheriting maternal surnames that carried genealogical capital. Regidor perpetuo Hernán Pérez de Valenzuela, Doña Isabel de Sotomayor's father, was born c.1514 in Almonte, Huelva, son of Captain Alonso de Lepe and Catalina Pérez. Don Alonso de Lepe was the brother of conquistador Hernando de Lepe. Both arrived to Puerto Rico in 1513 and joined their brother Don Alonso de Molina, a scribe and member of the nascent local elite. Their prominence as pioneers, conquistadors, and early colonizers was evident in their privileged positions, marriages to other noble families, and wealth. Alonso, Hernando, and Juan de Lepe were sons of Captain Diego de Lepe and Leonor Gonzalez de Villareal. The other brother, Don Alonso de Molina, was a son of Don Diego de Lepe, but we are unsure if he was a son of Leonor. All four brothers were grandsons of Captain Diego de Lepe, who lived in Palos de la Frontera, Huelva, Spain at the end of the fifteenth century. This Lepe family enjoyed a level of prominence in Spain and was related to the family of Conquistador Vicente Yáñez Pinzón. ${ }^{109}$ In a testimony from 1555, Hernán Pérez de Valenzuela declared that he was just over forty years old. ${ }^{110}$ Hernán (or Fernán, as he appears in his will) was one of the most distinguished, wealthy, and powerful individuals in Puerto Rico at that time - being for a few years Lieutenant Governor - and considered as such by his peers and historians alike. According to testimony by Baltazar Ramírez on a decree of grace from Pedro Menendez Covian on January 25, 1590:

Pedro Menéndez Covian married Doña Beatriz del Rincon daughter of Hernan Perez late vecino and rejidor of this city principal man (hombre principal) in said city and of the oldest settlers of the island and who was lieutenant governor for many years .... ${ }^{11}$

He was an hombre principal (this phrase was used to describe hidalgos, the Spanish term for the old nobility ${ }^{112}$ ), and therefore belonged to Castilian nobility. This status is clear in the declaration of service by Captain Diego Menéndez de Valdés from 1659 when he declared that Juan de Lugo Sotomayor, grandson of Hernán Pérez, and his wife Doña Luisa Velázquez were "hidalgo nobles, commonly known as such in the 


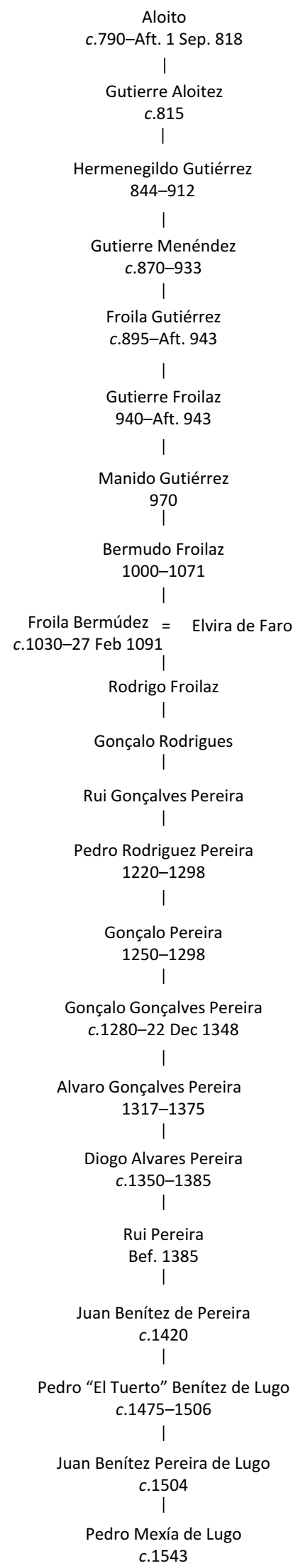

Figure 8. Paternal ancestors of Pedro Mexía de Lugo. 


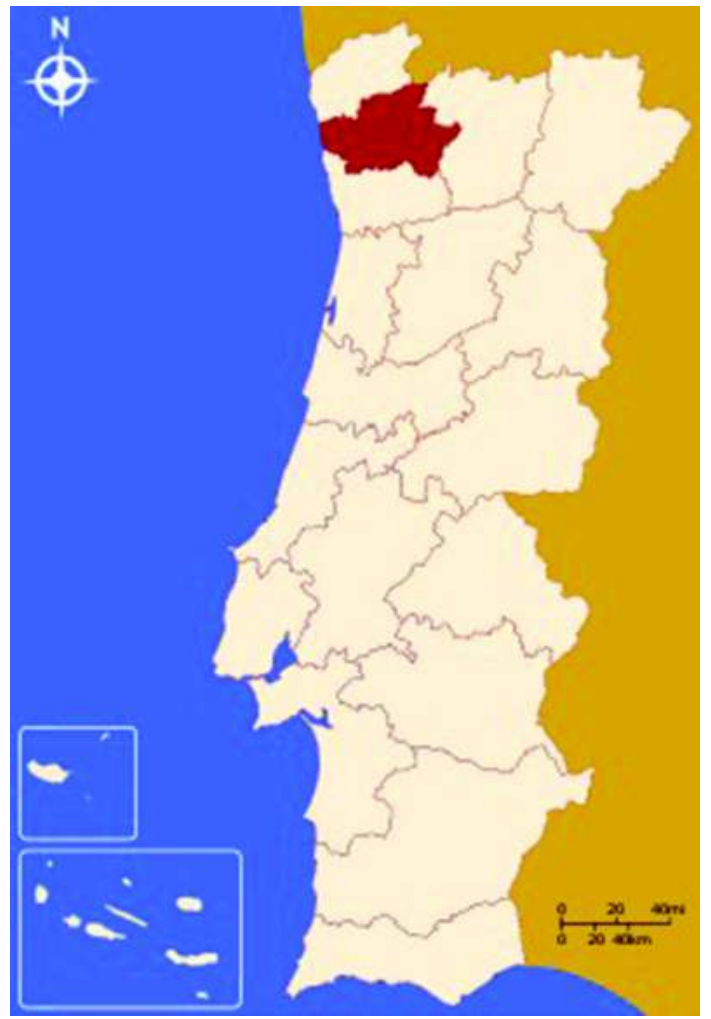

Figure 9. Map of Braga district, Portugal. Taken from Rei-artur. Wikipedia (with licence).

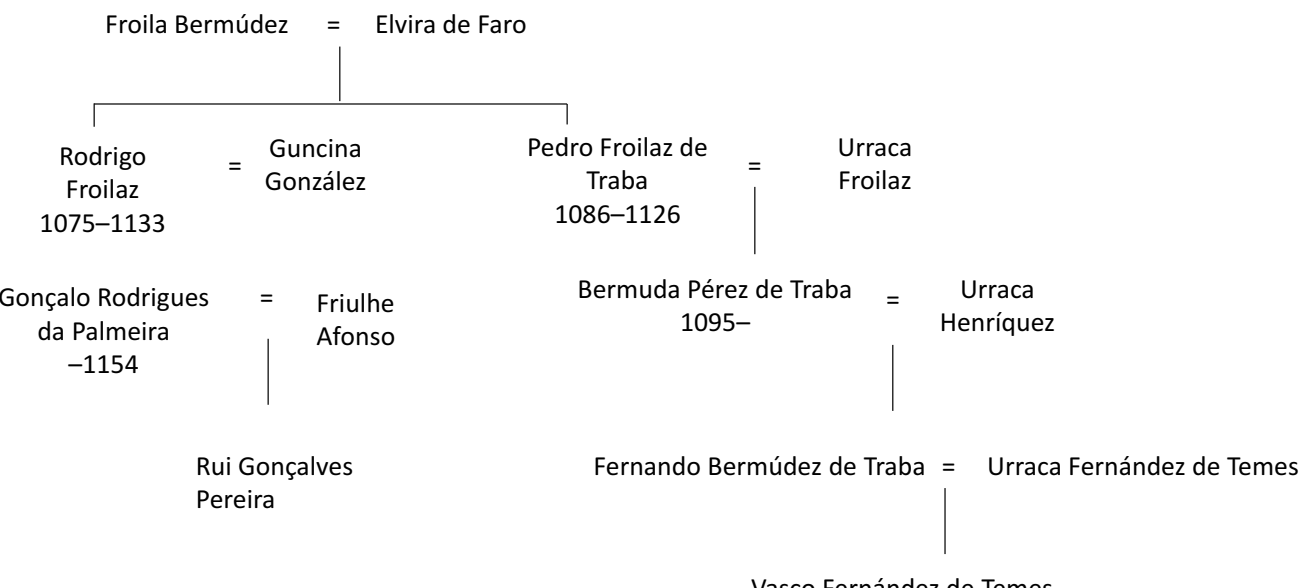

Vasco Fernández de Temes

Figure 10. Descendants of Count Froila Bermúdez.

entire city." For the most part, nobility is an inherited status. ${ }^{13}$ The available documentation does not indicate who his maternal grandparents were, but we do have some clues. In addition to Isabel de Sotomayor, two of his other daughters were Catalina Pérez de Valenzuela and Francisca de Escobar. ${ }^{114}$ Given that none of his descendants used the surname Lepe, I think the surnames with more genealogical capital among his ancestors were Pérez de Valenzuela (the compound variant of this Andalusian lineage) and Sotomayor.

A generation before Catalina Pérez de Valenzuela, in Extremadura, Castile, we have the marriage of Don Fernando de Sotomayor and Doña Catalina de Valenzuela, members of two distinguished noble lineages. ${ }^{115}$ (This couple had the following sons: Don Alonso, Don Diego and Don Fabián de Sotomayor y Valenzuela; the latter was a knight in the Order of the Hospitallers. ${ }^{116}$ ) Don Fernando de Sotomayor was probably born between 1465 and 1470 (based on the birth date of his grandfather, Don Fernando de Sotomayor, who requested the Bishop of Coria position in $1445,{ }^{117}$ which would place the birth 


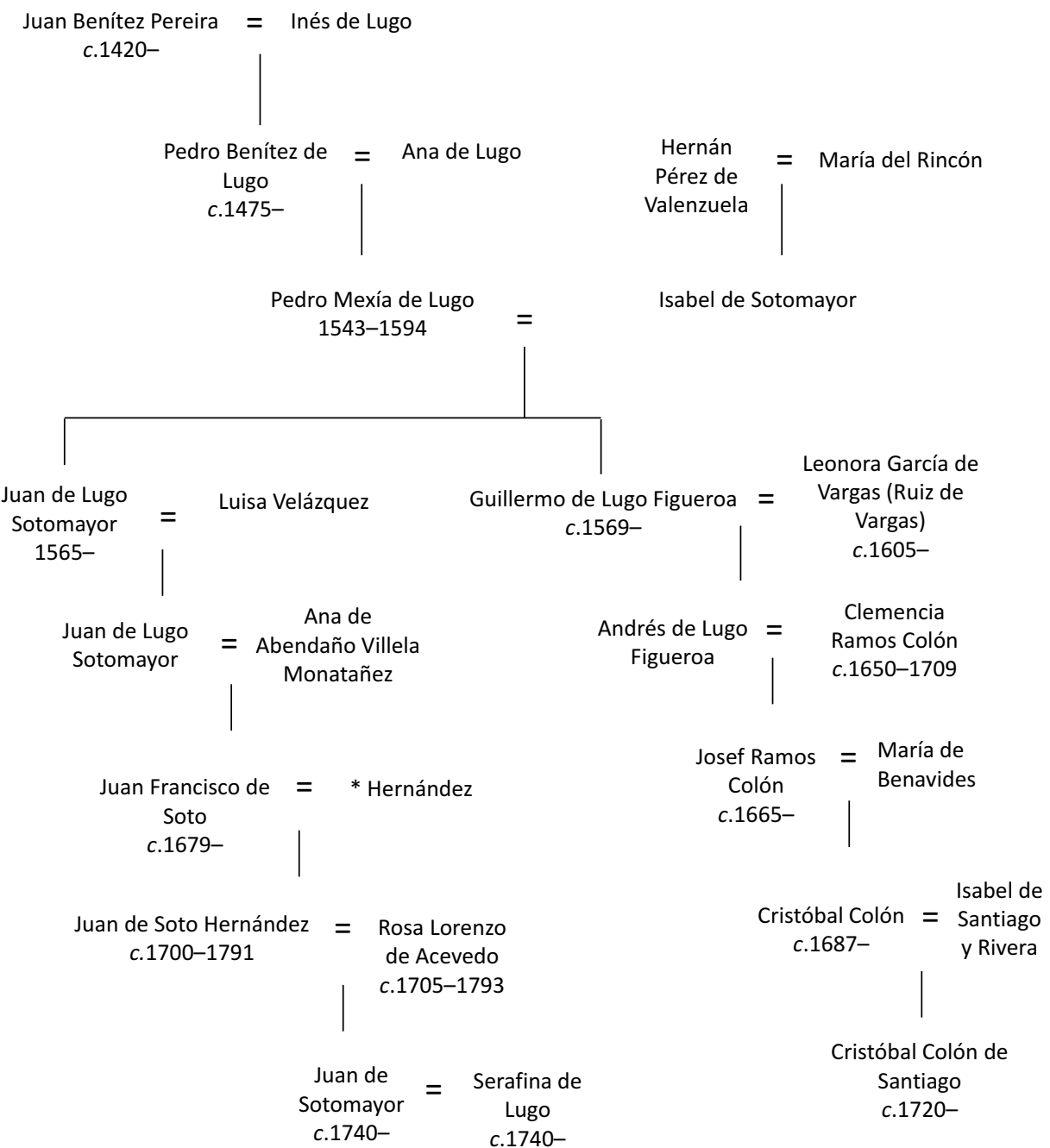

Figure 11. Hourglass chart of Pedro Mexía de Lugo.

date of Catalina de Valenzuela c.1490/95, who could have given birth to Hernán Pérez c.1515. If this Don Fernando requested the bishop's position at the age of twenty-five or thirty, he was born between 1415/1420, his son Fabián c.1440/1445, Don Fernando c.1465/70, and Catalina c.1490/95).

Don Fernando and Doña Catalina were also hidalgos since Don Fernando de Sotomayor belonged to a well-known noble family. He was the son of Don Fabián de Sotomayor and Doña Constanza de Zúñiga, grandson of Don Fernando de Sotomayor and Doña Teresa de Rol, and great-grandson of Don Gutierre de Sotomayor, Grand Master of the Order of Alcántara and Lord of Puebla de Alcocer, Alconchel, and Gahete, among others (born c.1395/1400). ${ }^{18,119}$ Catalina was a common name in the family of the Grand Master. His mother was named Catalina de Sotomayor and he also had two daughters named Catalina. ${ }^{120}$ The fact that Hernán Pérez also appears as Fernán is also a good clue because in Spanish and Portuguese Fernán is a common contraction of Fernando, and the letters $\mathrm{H}$ and $\mathrm{F}$ were commonly switched. Therefore, he was given the name of his maternal grandfather and third grandfather and the surname of his mother. Additionally, Don Gutierre's descendants, once married into the house of Zúñiga to form the powerful Zúñiga Sotomayor lineage, ${ }^{121}$ were counts of Belalcázar and relatives of the lords of different places in Huelva, particularly in Lepe, Gibraleón, and Ayamonte very close to Almonte where Hernán was born. ${ }^{122}$ Plus, Fernando's mother was a Zúñiga. The lordship of the Sotomayors in Extremadura also included the lands of Trujillo where the lineage Escobar also flourished during the fifteenth century, in alliance with another early lineage in Puerto Rico, the Añascos. ${ }^{123}$

Doña Catalina de Valenzuela also descended from an hidalgo family. She was daughter of Don Diego de Valenzuela (knight of the Order of Santiago) and Doña Francisca de Valenzuela. Diego was the son of Don Jerónimo de Valenzuela and Doña María Clavijo, and grandson of Don Juan Rodríguez de Valenzuela and Doña Gracia Rodríguez de Pineda Baena. One of Catalina's great-uncles was named Don Juan Pérez de Valenzuela. Diego was, in turn, great-grandson of Don Pedro Fernández de Valenzuela and Doña Juana Fernández de Córdoba. Pedro's father was 
Alonso or H/Fernando de Sotomayor Juan Pérez de Valenzuela

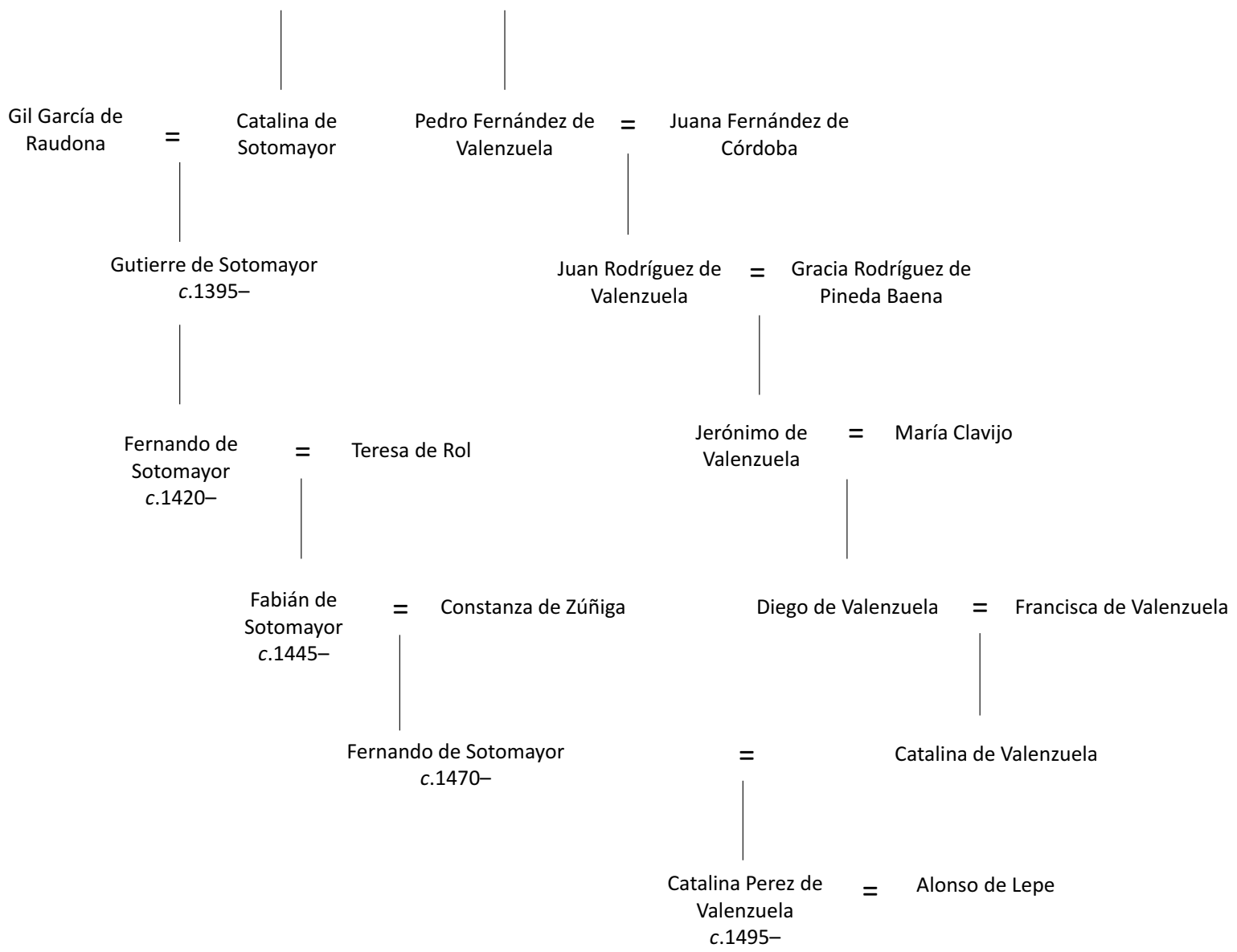

Figure 12. Ancestors of Catalina Pérez de Valenzuela Sotomayor.

Don Juan Pérez de Valenzuela, Seventh Lord of Valenzuela. ${ }^{124}$ Despite the generational distances, this house of Valenzuela is known for commonly using the patronymics Pérez and Fernández, ${ }^{125}$ hence the name Catalina Pérez de Valenzuela. Considering the dates, proper names - especially Catalina, Hernán's grandmother, mother, and daughter, all Valenzuela, clear onomastic chain; and even Fernán(do) - the surname Sotomayor (and even Escobar), location, and noble status, I think we have good reasons to propose this genealogy (see Figure 12).

\section{Conclusion}

For more than a decade now, genetics has been heralded as an important tool for those genealogies that have inadequate or unclear documentation. This is the case of a branch of the Sotomayor and Colón de Santiago families from Moca/Aguada pre-1700s. In this study, I have established an agnatic paternal genealogy for these families. We must clarify that the genealogy hereby presented is exclusive to the descendants of Juan de Sotomayor and Serafina de Lugo, my 5th-great-grandparents, to those who can prove being a descendant of Juan de Soto Hernández (1700), and to those who also descend from Cristóbal Colón de Santiago (1720). Genetic results also indicate that not all of the Sotomayors in the north-west of Puerto Rico have a direct paternal ancestor in common. In other words, not all of the Sotos and Sotomayors in Puerto Rico match on the $\mathrm{Y}$ chromosome. This indicates that there were several maternal events (inheritance of the Soto and Sotomayor surname from a mother other than Doña Isabel de Sotomayor) or cases of illegitimacy. We need more research to sort through these different families.

The dissonance between same surnames and Y-DNA, in turn, evidences the anthroponymical practice in the Spanish world of adoption of maternal ancestral surnames. As our Sotomayor-Colón case evidences, there were multiple cases of maternal surname inheritance among the noble families in Puerto Rico. The practice was not exclusive to the island, but was evident in the Canary Islands before, and even in Iberia. Compound surnames were common among the elite in Puerto Rico (Lugo Sotomayor, Lugo Figueroa, Ramos Colón, Colón de Santiago, Lorenzo de Acevedo, Luciano de Fuentes, López de Victoria, Ramírez de Arellano, Colón de Luyando, etc.). These surnames were commonly shortened and often took either surname from each compound. As our case illustrates, some kept only the surname in the second order, (Lugo) Sotomayor and 
(Ramos) Colón. The first was further shortened to Soto, the second created a new compound surname, Colón de Santiago. However, this practice did not equate to matriarchy, as Puerto Rican society remained strongly patriarchal by the end of the Spanish regime. ${ }^{126}$ It meant, as shown by George Ryskamp, ${ }^{127}$ that family and lineage was holistic, not strictly patrilineal, and full use of genealogical capital was implemented.

The clues that point to Don Gutierre de Sotomayor ${ }^{128}$ as the Sotomayor ancestor of Doña Isabel de Sotomayor are promising. Particularly revealing is the marriage between Gutierre's great-grandson Fernando de Sotomayor, with a Catalina de Valenzuela a generation before the birth of Hernán Pérez de Valenzuela's mother. Ultimately, despite the lack of direct genealogical documentation, these genetic results and the historical analysis offer a good response to the agnatic background of this branch of Sotomayors and Colóns in Puerto Rico's north-west: the Pereiras from Canary Islands, before that from Portugal, and before that from Galicia/Asturias.

This last point is of special interest, potentially groundbreaking. For centuries it was believed that the Pereiras, and in turn the Froilaz/Trabas and a large number of Iberian early medieval nobility, descended from Visigoth families. ${ }^{129}$ Contemporary historians do not suggest any particular origin. ${ }^{110}$ The results of the present genetic-genealogy study suggest that the background of this powerful and influential family of the high medieval ages coincides with peoples of the Atlantic fringes of Europe, including another aristocratic lineage, the Stewarts of Scotland. If that is the case, new interpretations about the origins of these families, their motivations, and impact on the Iberian Peninsula could be pursued.

A thousand years later, descendants of this Galician nobility expanded outside the Iberian Peninsula toward the conquest of societies overseas, accelerating the process of human migrations towards the Atlantic Ocean. Five hundred years after this, two families - unaware of their relationship in Puerto Rico - discover, with the help of genetic science, the history of these steps through the passing of time. Even though it is a young field and one that is difficult to understand, genetic genealogy is beginning to provide good results for those without genealogical documentation, but who have isolated historical data. Instead of parish records, the common threads that link one generation to the other are microscopic cells and their unbreakable and unquestionable genetic component, inherited from body to body.

\section{Acknowledgments}

The author is grateful for the support and collaboration of Moisés Colón, Edwin Colón, Rosana Medina Peraza, Jaime Sotomayor, Gerry Sotomayor and other members of the Sotomayor and Colón families who participated in this study. A special thank you to Gloria González Fortes and the team and authorities in Galicia for their assistance and collaboration. Larry Walker, Paul Ó Dubtaiġ, Christopher McCown, Richard Stevens, and others in the DF41 FTDNA group for their help in understanding genetic science and for critical support to process Edwin Colón's Big Y-500 test are much appreciated. Thank you to Rodolfo Hernández Chávez for sharing his vast knowledge of Iberian genealogy and collaboration with the connections with the Fernández de Córdoba/ Temes lineage. Early sources of important support and help were David Stark, Elsa Gelpí Baiz, Antonio Pedro de Sottomayor, Eduardo Colón, Víctor Colón de Bonilla, Juan Sotomayor Pérez, Ellen Fernández-Sacco, and the Sociedad de Ancestros Mocanos, for which I am deeply thankful. Ana Oquendo Pabón read an early version of this essay in Spanish and provided important feedback and support. Special thanks to Debra Pagán; her generosity helps to build the field of Puerto Rican genealogy and family history. Thank you to the anonymous reviewers for their critical and very productive comments and suggestions. This paper does not necessarily reflect the views of the people mentioned above, and any errors or omissions are entirely the responsibility of the author.

\section{Citation information}

Cite this article as: Sotomayor, Antonio (2019) Genetic genealogy for the study of Puerto Rican, Spanish, and Portuguese family history: lessons from the Sotomayor, Colón, and Pereira families. Journal of Genealogy and Family History. 3(1). http://dx.doi.org/10.24240/ 23992964.2019.1234518

\section{References}

1. Volcker, Guillermo. (1963) Letter to Rafael Reichard, 16 October. Colección Haybée Reichard. https://archivonacional.com/Collection/Haydee.Reichard/Default.aspx?t= pHaEQfQD\&s=Sotomayor.

2. Sotomayor, Antonio. (2016) 'Challenges and alternatives to Caribbean family history and genealogy: archives and sources in Puerto Rico'. In: Delgadillo, Roberto, ed. Who are we really?: Latin American family, local and micro-regional histories and their impact on understanding ourselves. New Orleans, LA: SALALM Secretariat, Latin American Library, Tulane University. pp. 94-96.

3. de Moura, Ronald Rodrigues, et. al. (2015) Meta-analysis of Brazilian genetic admixture and comparison with other Latin America countries. American Journal of Human Biology. 27(5).
4. Wade, Peter, López-Beltrán, Carlos and Ventura Santos, Ricardo (2015) Genomic research, publics, and experts in Latin America: nation, race, and body. Social Studies of Science. 45(6).

5. Szászdi León-Borja, István. (2011) Vida y desventura de un letrado gallego, Don Cristóbal de Sotomayor, de secretario Real a alcalde Mayor en Yndias. Anuario da Facultade de Dereito da Universidade da Coruña. 15.

6. Gil-Loyzaga, Pablo E. (2007) Cuatro siglos de en Puerto Rico: descendientes de Antonio de los Reyes Correa y de Diego R. Colón de Luyando y sus vínculos familiares con los Loyzaga, Mexía-Casado y Rodríguez de Matos en los siglos XVI al XIX. Madrid: Editorial Vision Net.

7. Vila, Suso (2010) A casa de Soutomaior (1147-1532). A Coruña, Galicia: Editorial Toxosoutos. p. 26.

8. Vila, Suso (2012) Letter to Antonio Sotomayor, 29 January.

9. González-Paz, Carlos A. (2009) Una fortaleza medieval en el camino portugués a Santiago de Compostela. Cuadernos de Estudios Gallegos LVI(122).

10. Calderón Medina, Inés. (2017) Reyes, nobles y frontera. Entre la violencia y e parentesco en el espacio fronterizo galaico portugués (siglos XII-XIII). Cuadernos de Estudios Gallegos, 64(130). pp. 108, 112.

11. Salazar y Acha, Jaime de. (2006) Manual de genealogía española. Madrid: Ediciones Hidalguía. p. 311.

12. Burgos, Augusto de. (1860) Blasón de España: libro de oro de su nobleza: reseña genealógica y descriptiva de la Casa Real, la grandeza de España y los títulos de Castilla. Vol. 6. Madrid: M. Rivadeneyra. pp. 83-84

13. Vila, Suso. (2010) A casa de Soutomaior (1147-1532). A Coruña, Galicia: Editorial Toxosoutos. pp. 37-45, 303-16.

14. Conde Mora, Francisco G. (2005) Los Sotomayor. Orígenes, consolidación y hegemonía de un linaje en el obispado tudense durante el medievo. Estudios de Genealogía, Heráldica y Nobiliaria de Galicia. 4.

15. Conde Mora, Francisco G. (2005) 'Los Sotomayor. Ramificaciones de un linaje de origen gallego en tierras americanas.' In: Pardo de Guevara y Valdés, Eduardo, ed. Actas de la XI reunión americana de genealogía. España y América: Un escenario común. Santiago de Compostela, 10 al 14 de septiembre de 2002. Santiago de Compostela: Consejo Superior de Investigaciones Científicas Xunta de Galicia. Instituto de Estudios Gallegos "Padre Sarmiento." pp. 453-54.

16. Stark, David. (1992) Las familias Colón en Coamo. Boletín de la Sociedad Puertorriqueña de Genealogía. IV(2).

17. Colón Gaulden, Edmund. (1988) Colón families of the seventeenth century in Puerto Rico. Their roots and notable descendants. Orange, California: E. Colón Gaulden.

18. Oquendo Pabón, Ana. (2018) Letter to Antonio Sotomayor, June 23. 
19. Births. 11 February 1915. SOTOMAYOR MENDEZ, Antonio.

20. Deaths. Puerto Rico. Moca. 6 August 1791. SOTO HERNÁNDEZ, Don Juan de Nuestra Señora de la Monserrate, Book 6, f. 132.

21. Gómez Canedo, Lino. (1964) Los archivos históricos de Puerto Rico: Apuntes de una visita (enero a mayo 1960). San Juan de Puerto Rico: Archivo General de Puerto Rico. p. 99.

22. Sotomayor, Sonia. (2013) My beloved world. New York: Vintage Books. p. 156.

23. Puerto Rico Gobernadores Españoles. Extranjeros (Foreigners in Puerto Rico), ca 1807-1880. Puerto Rico, Aguada. Box \#115C, FHL INTL Film 1389445. Items 1-3, transcription by María Kreider. https://www.familysearch.org/search/collection/ 1919700.

24. Nieves Acevedo, Benjamín. (2009) Historia de Aguada: Siglos XVI-XIX. Aguada: Editorial Aymaco. pp. 44-6.

25. Suárez Fernández, Luis. (1984) Historia general de España y América: América en el siglo XVII. Evolución de los reinos indianos. Tomo IX-2. Madrid: Ediciones Rialp, S. A. p. 202.

26. Fernández Pérez, Enrique A. (2015) El nombre y los apellidos. Su regulación en derecho español y comparado. PhD thesis, Universidad de Sevilla. pp. 119-136.

27. Piñero Rivera, Luis Orlando. Irregularidad de los apellidos españoles hasta el siglo XIX Mendoza: Poderosos Señores. https://www.uam.es/personal_pdi/ciencias/depaz/ mendoza/mapellid.htm.

28. Alfaro de Prado, Antonio. La ¿caótica? transmisión de apellidos hasta el siglo XIX en España. Genealogía Hispana. https://www.genealogiahispana.com/apellidos/la-cao tica-transmision-de-apellidos-hasta-el-siglo-xix-en-espana/.

29. López Benito, Clara I. (1991) Don Francisco de Sotomayor - Clavero de Alcántara un prototipo de caballero en la temprana Edad Media. Studia Historica. Historia Moderna, IX. pp. 218-20

30. Barredo de Valenzuela, Adolfo. (1999) Nobiliario de Extremadura. Vol. 4. Madrid: Hidalguía. p. 245

31. Soto, Luis de. (2017) Isabel de Bobadilla y Hernando de Soto. 8 June. https://www. heraldaria.com/phorum5/read.php?3,17676.

32. Vila, Suso (2010) A casa de Soutomaior (1147-1532). A Coruña, Galicia: Editorial Toxosoutos

33. Murga Sanz, Vicente and Huerga, Álvaro. (1961) Cedulario puertorriqueño. Tomo (1505-1517). Río Piedras: Ediciones de la Universidad de Puerto Rico. pp. 372-73.

34. Sottomayor, António Pedro de. (2014) Letter to Antonio Sotomayor, 25 November.

35. Tapia y Rivera, Alejandro. (1970) Biblioteca histórica de Puerto Rico que contiene varios documentos de los siglos XV, XVI, XVII y XVIII. San Juan de Puerto Rico: Instituto de Cultura Puertorriqueña. p. 286

36. Murga Sanz, Vicente and Huerga, Álvaro. (1961) Cedulario puertorriqueño. Tomo (1505-1517). Río Piedras: Ediciones de la Universidad de Puerto Rico. pp. 54-55.

37. Corbalán de Celis y Durán, Juan. (2015) Unas notas sobre los Álvarez de Sotomayor y Antonio de Villalba, gobernadores de Melilla. Akros: Revista de Patrimonio. 14. p. 16.

38. del Castillo Ruiz de Molina, Sebastián. (1741) Noticias genealógicas de la antigua familia de Aranda, de la que justifica su descendencia D. Joaquín de Randa y Amézaga.... pp. 55-56.

39. Corbalán de Celis y Durán, Juan. (2015) Unas notas sobre los Álvarez de Sotomayor y Antonio de Villalba, gobernadores de Melilla. Akros: Revista de Patrimonio. 14. p. 17.

40. Corbalán de Celis y Durán, Juan. (2015) Unas notas sobre los Álvarez de Sotomayor y Antonio de Villalba, gobernadores de Melilla. Akros: Revista de Patrimonio. 14. p. 18

41. Morales, Gabriel de. (1995) Efemérides de la Historia de Melilla (1497-1913). Melilla: Centro Asociado UNED de Melilla. pp. 54-5.

42. Archivo Histórico Nacional, Consejo de Órdenes, ES.28079.AHN/1.1.13.8.4//OMCABALLEROS_SANTIAGO,Exp.7880.

43. Ryskamp, George R. (2000) The intergenerational transmission of surnames in Spain, 1500-1900. La Vie Genealogique. 28 (Acts of the 24th International Congress on Genealogical and Heraldic Sciences, Besançon, France, 5-7 May 2000). pp. 317-30.

44. Tëtushkin, E.Ya. (2011) Genetic genealogy: history and methodology. Russian Journal of Genetics. 47(5). pp. 507-20.

45. Oquendo Pabón, Ana C. (2005) Genetic genealogy and Puerto Rican genealogy unlikely allies (La genealogía genética y la genealogía Puertorriqueña: aliados inverosímiles). Hereditas : revista de genealogía puertorriqueña. 6(2). pp. 7-23.

46. Calafell, Francesc and Larmuseau, Maarten H. D. (2017) The Y chromosome as the most popular marker in genetic genealogy benefits interdisciplinary research. Human Genetics. 136(5). pp. 564-65.

47. Calafell, Francesc and Larmuseau, Maarten H. D. (2017) The Y chromosome as the most popular marker in genetic genealogy benefits interdisciplinary research. Human Genetics. 136(5). pp. 562-63.

48. Bettinger, Blaine T. (2016) The family tree: guide to DNA testing and genetic genealogy. Cincinnati, Ohio: Family Tree Books. pp. 82-3.
49. Jobling, Mark, Hollox, Edward, Kivisild, Toomas, and Tyler-Smith, Chris. (2014) Human evolutionary genetics. New York: Garland Science. p. 173

50. Bettinger, Blaine T. (2016) The family tree: guide to DNA testing and genetic genealogy. Cincinnati, Ohio: Family Tree Books. pp. 78-80

51. Walker, Larry. (2017) Letter to Antonio Sotomayor, 29 November.

52. Solé-Morata, Neus, Villaescusa, Patricia, García-Fernández, Carla, et. al. (2017) Analysis of the R1b-DF27 haplogroup shows that a large fraction of Iberian Ychromosome lineages originated recently in situ. Scientific Reports. 7(7341). pp. $1-13$.

53. Flood, Joe. (n.d.) The phylogenealogy of R-L21: four and a half millennia of expansion and redistribution. Working paper. https://www.academia.edu/ 24686284/The_phylogenealogy_of_R-L21_four_and_a_half_millennia_of_expan sion_and_redistribution.

54. Lucotte, Gérard. (2015) The major Y-chromosome haplogroup R1b-M269 in WestEurope, subdivided by three SNPs S21/U106, S145/L21 and S28/U152, shows a clear pattern of geographic differentiation. Advances in Anthropology. 5. p. 26.

55. Campos Calvo-Sotelo, Javier. (2017) / Celti, la prima Europa: the role of Celtic myth and Celtic music in the construction of European identity. Popular Music and Society. 40(4). pp. 369-89.

56. Hernández Chávez, Rodolfo. (2015) Letter to Antonio Sotomayor, 3 March.

57. Cordero Ponce de León, Antonio. (2016) Armas de los Fernández de Córdoba, descendientes del linaje gallego de los Fernández de Temes, en la Heráldica Municipal Andaluza. Estudios de Genealogía, Heráldica y Nobiliaria de Galicia, 13 pp. 411-20.

58. González, Eva. (2015) En busca del linaje de Pedro Madruga en Tui. Faro de Vigo. 20 August. http://www.farodevigo.es/sociedad-cultura/2015/08/20/busca-linajepedro-madruga-tui/1299215.html.

59. Vilas, Alberto (2015) Tras el linaje de Pedro Madruga. El Progreso. 28 August. https:// www.elprogreso.es/articulo/galicia/tras-el-linaje-de-pedro-madruga/ 20150828212101356178.html.

60. González Fortes, Gloria. (2017) Letter to Antonio Sotomayor, 24 April.

61. Testamentary records. Algeria. 17 November 1653. COLÓN DE TOLEDO, Doña Petronila. Will and testament. Archivo Histórico de Protocolos de Madrid. T7487. f. $108 \mathrm{r}-114 \mathrm{v} . \mathrm{F}=14$.

62. Archivo General de Indias. Santo Domingo. Legajo 163. F. 83

63. Cuesta y Camacho, David Enrique and Castro Lombart, Teresa de. (2002) Los antepasados y descendientes de Don Diego Menéndez de Valdés: Gobernador de Puerto Rico desde 1582 hasta 1593. Unpublished manuscript. p. 17

64. Pagán, Debra. Santo Domingo. Book 2. March 3, 1674, f. 201-205v.

65. Archivo General de Indias. Indiferente General. Legajo 199. n.43, f.252.

66. Ramírez Brau, Enrique. (1942) Orígenes puertorriqueños del año 1653 al 1853. Tomo 1. San Juan, Puerto Rico: Imprenta Baldrich. p. 222.

67. Marriages. Puerto Rico. 16 November 1665. LUGO SOTOMAYOR, Juan de and AVENDAÑO, Ana de. San Juan, Nuestra Señora de los Remedios. Book 1 (16531701). f.90, image 105. Puerto Rico, Catholic Church Records, 1645-1969. https:// familysearch.org.

68. Marriages. Puerto Rico. 18 Jun 1668. LUGO SOTOMAYOR, Francisco, de and NEGRETE, Gerónima Muxica. Nuestra Señora de los Remedios. San Juan. Book 1 (1653-1701), f.101, images 115-116. Puerto Rico, Catholic Church Records, 16451969. https://familysearch.org

69. de Castro, Teresa and Stark, David. (1997) Padrón del año 1673 de las personas que hay en la ciudad de San Juan de Puerto Rico: Una transcripción con introducción y notas genealógicas.

70. Ramírez Brau, Enrique. (1942) Orígenes puertorriqueños del año 1653 al 1853. San Juan, Puerto Rico: Imprenta Baldrich. p. 7.

71. Brau, Enrique Ramírez. (1943) Orígenes portorriqueños del año 1653 al 1853. Tomo Il. San Juan, Puerto Rico: Imprenta Baldrich, pp. 58-59.

72. Archivo General de Indias. Legajo 2295.

73. Archivo General de Indias. Escribanía de Cámara. Legajo 135C. Comisiones.

74. (1966) Actas del cabildo de San Juan Bautista de Puerto Rico. San Juan de Puerto Rico. p. 203.

75. (1966) Actas del cabildo de San Juan Bautista de Puerto Rico. San Juan de Puerto Rico. p. 203.

76. Archivo General de Puerto Rico. Fondo de Gobernadores Españoles. Serie: Municipalidades - Moca, Caja 509. Transcription by Luis R. Burset Flores.

77. Deaths. Puerto Rico. Lares 1889-1894, Book 7-13, f. 122, \#111. Collection: Puerto Rico, Registro Civil, 1805-2001; Lares > Defunciones 1889-1894, L. 713 > image 1761 of 2282; oficinas del ciudad, Puerto Rico https://familysearch. org/ark:/61903/3:1:939Z-RKSM-BN?cC=1682798\&wC=9PTY-GP8\%3A129442101\% 2C129541601. 
78. Deaths. Puerto Rico. Adjuntas. 29 August 1890. COLÓN Y LÓPEZ, Francisco. Collection: Puerto Rico, Registro Civil, 1805-2001. 1890-1899, f. 79v. \#107. Adjuntas > Defunciones 1890-1899 > image 126 of 2737; oficinas del ciudad Puerto Rico. https://familysearch.org/ark:/61903/3:1:939D-72QN-6?cc= 1682798\&wC=9P5J-GP8\%3A129443601\%2C129582701.

79. Marriages. Puerto Rico. Moca. 7 August 1798. COLÓN DE SANTIAGO Y SALAS, Antonio and VELÁZQUEZ RODRíGUEZ, María. APINSMM L.2, f. 28v. \#20, San Antonio, 1180 c, p. 231.

80. Deaths. Puerto Rico. Moca. 15 September 1886. COLÓN VELÁZQUEZ, Francisca. Collection: Puerto Rico, Registro Civil, 1805-2001. 1886-1887, f. 260, \#211. Moca > Defunciones 1886-1887 > image 140 of 302; oficinas del ciudad, Puerto Rico. https://familysearch.org/ark:/61903/3:1:9398-VXQZ-R?cc=1682798\&wC=9PP2-3TL\% 3A129439901\%2C129439802

82. Archivo General de Puerto Rico. Fondo de Gobernadores Españoles. Serie: Municipalidades - Moca. Caja 547. Transcription by Walter A. Cardona Bonet

82. Méndez Muñoz, Andrés. (2004) Pobladores en los procesos de fundación de pueblos en el Partido de San Francisco de la Aguada durante el siglo XVIII. Hereditas : revista de genealogía puertorriqueña. 5(1). p. 14.

83. Baptisms. Puerto Rico. Coamo. 9 May 1714. COLÓN DE BONILLA, Marcos. Iglesia del Valle de San Blas Illescas de Coamo. Book 1. f. 58v. \#427.

84. Marriages. Puerto Rico. San Germán. Book 1, 1759-1774.

85. Devine, Donn. How long is a generation? Science provides an answer. https://isogg org/wiki/How_long_is_a_generation\%3F_Science_provides_an_answer.

86. Archivo General de Indias. Santo Domingo. Legajo \#2295.

87. Méndez Muñoz. (2004) Pobladores en los procesos de fundación de pueblos en el Partido de San Francisco de la Aguada durante el siglo XVIII. Hereditas : revista de genealogía puertorriqueña. 8(1). pp. 6-7.

88. Méndez Muñoz, Andrés. (2004) Pobladores del Partido de San Francisco de la Aguada para comienzos del siglo XVIII. Hereditas : revista de genealogía puertorriqueña. 8(1). pp. 56, 64

89. Fernández-Sacco, Ellen. (2015) List of early Acevedo, Santiago, Cordero / Mendez in Aguada, 1699-1727. Unpublished manuscript. 2 pages.

90. Méndez Muñoz, Andrés. (2007) Pobladores del Partido de San Francisco de la Aguada en los juicios de residencia para principios del siglo XVIII. Hereditas : revista de genealogía puertorriqueña. 8(1). pp. 7-8

91. Stark, David. (1995) Reconstructing Puerto Rico's population history (the militia muster rolls compiled in 1700 by Gabriel Gutiérrez de Riva as tools for genealogical and historical research). Hereditas : revista de genealogía puertorriqueña. 7(1-2). p. 33.

92. Stark, David. (1995) Reconstructing Puerto Rico's population history (the militia muster rolls compiled in 1700 by Gabriel Gutiérrez de Riva as tools for genealogical and historical research). Hereditas : revista de genealogía puertorriqueña. $7(1-2)$ p. 46

93. Méndez Muñoz, Andrés. (2004) Pobladores del Partido de San Francisco de la Aguada para comienzos del siglo XVIII. Hereditas : revista de genealogía puertorriqueña. 8(1). pp. 54-71.

94. Méndez Muñoz, Andrés. (2005) Resistencia a curatos en el Partido de San Francisco de la Aguada. Hereditas : revista de genealogía puertorriqueña. 6(1) pp. $81-83$.

95. Méndez Muñoz, Andrés. (2007) Pobladores del Partido de San Francisco de la Aguada en los juicios de residencia. Hereditas : revista de genealogía puertorriqueña. 8(1). pp. 3-15.

96. Méndez Muñoz, Andrés. (2007) Participación de los pobladores de la Villa de San Germán en la defensa de la isla durante la primera mitad del siglo XVII. Hereditas revista de genealogía puertorriqueña. 8(2). pp. 34-36.

97. Méndez Muñoz, Andrés. (2004) Pobladores del Partido de San Francisco de la Aguada para comienzos del siglo XVIII. Hereditas : revista de genealogía puertorriqueña. 8(1). p. 3

98. Eizaguirre, José M. (1984) Apuntes sobre la endogamia 'blanca' en Puerto Rico (siglos XVI al XIX). Cupey. 1(2). pp. 15-33.

99. O'Neill, Edwin B. and McLaughlin, John D. (2006) Insights into the O'Neills of Ireland from DNA testing. Journal of Genetic Genealogy. 2. pp. 18-26.

100. Fernández de Béthencourt, Francisco. (1878) Nobiliario y blasón de Canarias. Diccionario histórico, biográfico, genealógico y heráldico de la provincia. Tomo I. Santa Cruz de Tenerife: Imprenta Isleña y Encuadernación de Libros de Francisco C. Hernández. pp. 56-9.

101. Salazar y Acha, Jaime de. (2006) Manual de genealogía española. Madrid: Ediciones Hidalguía. p. 163

102. Cabrera Benítez, Javier. (2018) La rama mayor de la familia Benítez de Lugo: un studio de historia familiar a través del fondo documental Benítez, perteneciente a la Biblioteca Municipal de Santa Cruz de Tenerife. Thesis, Universidad de La Laguna.
https:/riull.ull.es/xmlui/bitstream/handle/915/9964/La\%20rama\%20mayor\%20de\% 20la\%20familia\%20Benitez\%20de\%20Lugo\%20un\%20estudio\%20de\%20historia\% 20familiar\%20a\%20traves\%20del\%20fondo\%20documental\%20Benitez\%2C\%20per teneciente\%20a\%20la\%20Biblioteca\%20Municipal\%20de\%20Santa\%20Cruz\%20de \%20Tenerife\%20.pdf? sequence $=1$ \&isAllowed $=y$.

103. Gouveia Monteiro, João. (2017) Nuno Álvares Pereira-Guerreiro, senhor feudal santo: Os Três Rostros do Condestável. Lisboa: Manuscrito. pp. 160-63.

104. Pizarro, José Augusto de Sottomayor. (1997) Linhagens medievais portuguesas: genealogias e estrategias (1279-1325). Vol. II. PhD thesis, Universidade do Porto. pp. 877-78.

105. López Sangil, José L. (2002) La nobleza altomedieval gallega. La familia FroilazTraba. Noia, Spain: Editorial Toxosoutos.

106. Torres Sevilla-Quiñones de León, Margarita Cecilia. (1998) Relaciones fronterizas entre Portugal y León en tiempos de Alfonso VII: El ejemplo de la Casa de Traba. História. 15. pp. 301-12.

107. Vilar y Pascual, Luis. (1860). Diccionario histórico, genealógico y heráldico de las familias ilustres de la monarquía española. Vol. 5. Madrid: Imprenta de D. F. Sánchez a cargo de Agustín Espinosa, pp. 108-114.

108. Calderón Medina, Inés. (2017) Reyes, nobles y frontera: entre la violencia y el parentesco en el espacio fronterizo galaico portugués (siglos XII-XIII). Cuadernos de Estudios Gallegos, 64. pp. 94-95.

109. Cuesta y Camacho, David, de la Terga, Ricardo José Antonio, and Cofré León, Cristián. (2009) La historia y genealogía de Diego de Lepe de la villa de Palos de la Frontera, Puerto Rico y Chile. Hereditas : revista de genealogía puertorriqueña. 10(2). pp. 76-102.

110. Archivo General de Indias. Justicia. Legajo 81. "Residencia de Gonzalo Bernal ...".

111. Archivo General de Indias. Indiferente General. Lejago 1241.Gelpí Báiz, Elsa. (2007) Siglo en blanco: Estudio de la economía azucarera en Puerto Rico, siglo XVI. Río Piedras: Editorial de la Universidad de Puerto Rico. p. 174. see

112. Malagón Barceló, Javier. (1968) Toledo y el nuevo mundo en el siglo XVI. Anales Toledanos 2. p. 98.

113. Archivo General de Indias. Indiferente General. Legajo 118. \#118.

114. Testamentary records. Puerto Rico. 7 December 1594. PÉREZ, Hernán. Testament and will. Archivo General de Indias. Contaduría. f. 662. Transcription by Lorrain de Castro.

115. Valdés Carrera, Antonio. (1888) Revolución chilena y campañas de la independencia, con un apéndice sobre la jenealojía de la familia del Jeneral. Santiago: Imp. de la Unión de E. del Campo. p. 508.

116. Ramón Zapater, Miguel. (1662) Cister militante en la campaña de la Iglesia contra la sarracena furia: historia general de las Ilustrísimas, Inclitas y Nobilisimas Cavallerías del Templo de Salomón, Calatrava, Alcántara, Avis, Montesa y Christo. Agustín Verges. p. 499.

117. Ortega Álvarez, Javier. (2010) La 'Casa' de Don Gutierre de Sotomayor, Maestre de Alcántara: una aproximación a la prosopografía de la Orden de Alcántara. Revista de Estudios Extremeños. 66(1). p. 275.

118. Torres y Tapia, Alonso. (1763) Crónica de la Orden de Alcántara. Tomo II. Madrid: Don Gabriel Ramírez. p. 342.

119. Ortega Álvarez, Javier. (2011) El acceso de don Gutierre de Sotomayor al Maestrazgo de la Orden de Alcántara: orígenes y consecuencias. Espacio, Tiempo y Forma, serie III, Historia Medieval. 24. p. 241.

120. Ortega Álvarez, Javier. (2010) La 'Casa' de Don Gutierre de Sotomayor, Maestre de Alcántara: una aproximación a la prosopografía de la Orden de Alcántara. Revista de Estudios Extremeños. 66(1). p. 275.

121. Vicens Hualde, María. (2017) De caballeros a cortesanos: evolución del linaje de los Zúñiga hasta el I Marqués de Villamanrique. Historia y Genealogía. 7. p. 73.

122. Sánchez Saus, Rafael. (1988) Los señores de Ayamonte y Lepe: Guzmanes y Stuñigas en el siglo XV (1396-1454). Huelva en su Historia. 2. pp. 161-74.

123. Fernández-Daza Alvear, Carmen. (1985) 'Linajes trujillanos y cargos concejiles en el siglo XV'. In: Sáez Sánchez, Emilio, Segura Graíño, Cristina, and Cantera Montenegro, Margarita, eds. La ciudad hispánica durante los siglos XIII al XVI. Actas del Coloquio celebrado en la Rábida y Sevilla del 14 al 19 de septiembre de 1981. Bd. 1. Madrid: Editorial de la Universidad Complutense. p. 424.

124. Valdés Carrera, Antonio. (1888) Revolución chilena y campañas de la independencia, con un apéndice sobre la jenealojía de la familia del Jeneral. Santiago: Imp. de la Unión de E. del Campo. p. 508

125. Quintanilla Raso, María Concepción. (1982) 'Estructuras sociales y familiares y papel político de la nobleza cordobesa (siglos XIV y XV)'. In: Ladero Quesada, Miguel Ánge and Moxó, Salvador de, eds. Estudios en memoria del Profesor D. Salvador de Moxó, II. Madrid: Universidad Complutense. p. 336

126. Suárez-Findley, Eileen. (1999) Imposing decency: the politics of sexuality and race in Puerto Rico, 1870-1920. Durham, North Carolina: Duke University Press. pp. 24-7.

127. Ryskamp, George R. (2000) The intergenerational transmission of surnames in Spain, 1500-1900. La Vie Genealogique. 28 (Acts of the 24th International 
Congress on Genealogical and Heraldic Sciences, Besançon, France, 5-7 May 2000). pp. 317-30.

128. Cabrera Muñoz Emilio (1977) El Condado de Belalcázar 1444-1518: Aportación al estudio del régimen señorial en la Baja Edad Media. Córdoba: Monte de Piedad y Caja de ahorros de Córdoba. pp. 176-78.
129. Barcelos, Pedro Conde de. (1646) Nobiliario del Conde de Barcelos Don Pedro hijo del Rey Don Dionis de Portugal, traduzido casigado y con nuevas illustraciones por Manuel de Faria y Sousa. Paredes. p. 43.

130. López Sangil, José L. (2002) La nobleza altomedieval gallega. La familia FroilazTraba. Noia, Spain: Editorial Toxosoutos. p. 15.

\section{ABOUT THE AUTHOR}

Antonio Sotomayor is professor, historian, and librarian of Latin American and Caribbean Studies at the University of Illinois at Urbana-Champaign He obtained his PhD in history from the University of Chicago. An award-winning author, his work appears in journals such as The Latin Americanist, The Americas, Caribbean Studies, and Hispania Nova, and has been featured in major media outlets such as National Public Radio, NBC Sports, and Backstory. His interests in genealogy and heraldry go back fifteen years and he has published material about archives and sources for Puerto Rican genealogy and family history. See www.asotomayor.com

Email: asotomay@illinois.edu

https://orcid.org/0000-0001-6795-8772 